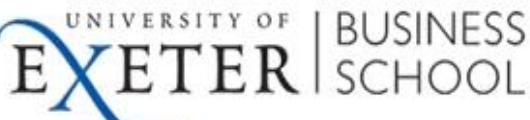

\section{Some New Models for Financial Distress Prediction in the UK}

\author{
Angela Chih-Ying Christidis \\ Xfi Centre for Finance \& Investment, University of Exeter \\ Alan Gregory \\ Xfi Centre for Finance \& Investment, University of Exeter \\ corresponding author: a.gregory@ex.ac.uk
}

\section{Xfi - Centre for Finance and Investment} Discussion Paper no: 10/04

This Version: September 2010

\begin{abstract}
In this paper we develop some new models for the prediction of failure in the UK that add to the literature by showing that "dynamic logit" models that incorporate market variables of the form developed by Chava and Jarrow (2004) and Campbell et al (2008) add considerable power to pure accounting-based models. Importantly, we extend the logic of Campbell et al (2008) by showing that incorporating macroeconomic variables adds predictive power, both in and out-of-sample, to market-based accounting models. Last, we show that adding industry controls gives a modest improvement to such models for UK firms in the case of a models based on accounting, market and economic variables, but a greater improvement in terms of a pure accounting based model.
\end{abstract}

JEL Classification: 633

We are grateful to David Gwilliam and Bill Rees for comments.

All errors remain the responsibility of the authors 


\section{Some New Models for Corporate Failure Prediction in the UK}

\section{Introduction}

Several recent papers have served to emphasise the need for a timely model of UK financial failure prediction, the parameters of which are fully in the public domain. First, Campbell, Hilscher and Szilagyi (2008) show that financially distressed firms have delivered anomalously low returns in the US. There is no UK equivalent to the model they use to estimate distress risk, something we attempt to address in this paper. Second, Pope (2010) suggests that factor mimicking portfolios based on financial distress risk may help deliver more powerful factor models of expected returns. In respect of the UK, this suggestion pre-supposes that an appropriate model is available. Of course, with regard to the latter one can make the case for using a model that is well-understood, such as the z-score models of Taffler $(1983,1984)$ and this is precisely the approach followed in Agarwal and Taffler (2008a), which provides some fascinating evidence that momentum may be a proxy for distress risk. However, in doing so it provides UK evidence that is consistent with the Campbell et al (2008) finding, leaving the conundrum that markets, apparently, do not adequately price distress risk. This alone motivates the search for a "better" distress prediction model that might resolve this anomaly. Third, Agarwal and Taffler (2007) note the dramatic increase in UK firms with "at risk" z-scores from 1997 onwards, which might imply the need for an updated UK prediction model. Fourth, Shumway (2001) shows that a "hazard" or "dynamic logit" model gives better predictive power than a simpler logit model. Chava and Jarrow (2004) develop this further by adding industry controls, and show that such a model can easily be estimated using standard statistical packages. As far as we are aware, these approaches to modelling, combined with the Campbell et al (2008) innovations, have not been attempted in the UK. However, in the current financial climate one scarcely needs to allude to the academic literature to justify an interest in a timely measure of failure prediction - the likely interest from the wider community in such a model is, regrettably, all too obvious.

In this paper, we do not devote a great deal of time to the discussion of the long earlier literature on corporate failure prediction and research methods, given a review can be found in Balcaen and Ooghe (2006). The basic choice in models is between 
what Balcaen and Ooghe (2006) term the "classic" statistical methodologies, by which they mean univariate and multivariate models that use accounting numbers, and what Agarwal and Taffler (2008b) term market-based models, a classification which encompasses a range of contingent claims models. We specifically do not use this latter approach in this paper, as Agarwal and Taffler (2008b) show that it fails to outperform a simple z-score model. Furthermore, Campbell et al (2008) conclude that a variant of the option-based approach, a distance to default model, does not adequately summarise default risk for US firms. So instead, we focus on developing market and accounting-based models in the spirit of Campbell et al (2008).

It is worth pausing to consider the theoretical justification for combining accounting and market data. One can, of course, criticise accounting-based models in general for lacking theoretical underpinnings, although Agarwal and Taffler (2007, p.298) make a reasonable counter-argument to this. Suppose one is prepared to accept that the use of accounting data can be justified by theory. There is, nonetheless, an issue of timeliness. Accounting data is necessarily out of date and added to this, distressed firms tend to be late reporting (e.g. Ohlson 1980; Lennox 1999). In such circumstances, combining accounting data with information in market prices may help overcome the timeliness problem. Beaver et al (2005) make a not dissimilar point and note that (p.110) "market prices reflect a rich and comprehensive mix of information, which includes financial statement data as a subset”. The particular market variables we consider here, following Campbell et al (2008), are the replacement of book values of assets with market values, together with six-month excess returns and standard deviation of returns. Note that this does not imply financial statement information is of limited value, as we show that accounting measures of profitability, cash flow and liabilities have an important role to play in financial distress prediction. However, an interesting characteristic of these enhanced models is that once market information is incorporated, simple accounting measures based on changes in income and dummy variables for loss-making firms are rendered irrelevant. This is particularly interesting given the fact that Agarwal and Taffler (2007, p.297) highlight the problems caused by the increase in loss-making firms. Finally, as we show that these enhanced models out-perform pure accounting-based models of the form investigated in Agarwal and Taffler (2007; 2008b), the 
implication is that these models should out-perform contingent claims based models, although we do not formally investigate this.

Several recent developments in the literature have involved the use of "hazard" or "dynamic logit" models, of the form first developed by Shumway (2001). He shows that single period logit models are mis-specified, leading to inference errors, and that his "hazard" model improves on a single-period logit model by explicitly accounting for time. Furthermore, he shows that such models can be estimated by standard logit programs in a simple and intuitive way (Shumway, 2001, p.111-112). Chava and Jarrow (2004) develop this further and show that the process is even simpler than Shumway (2001) suggests.

It is worth emphasising that none of these recent developments appears in the UK literature. Specifically with regard to the UK the earliest studies are due to Taffler (1982, 1983). Taffler (1984) provides a critical review of the outstanding features of the Z-score models documented in the UK. While a few studies in the U.S. find price level-adjusted ratios add incremental information over and above that provided by historic cost ratios (Ketz, 1978; Mensah, 1983), Keasey and Watson (1986) find that the current cost information does not improve the predictive accuracy of the models for small firms in the U.K. Peel, Peel, and Pope (1986) appears to be the earliest attempt to apply a logit-based analysis in the UK. Keasey and Watson (1991) conduct a detailed review of the usefulness of U.K. financial distress prediction models in a management context and show that an improvement in the predictive power might be primarily driven by the inclusion of more years of information. Lennox (1999) finds that profitability, leverage, and cash flow have important effects on the probability of bankruptcy on a sample of 90 bankrupt firms. Logit and probit models are found to perform better than MDA approaches in his study. His bankruptcy model shows a decline in accuracy for more distant bankruptcy horizons. Charitou et al (2004) employ a logit analysis and a neural networks methodology and use a dataset of 51 matched pairs of failed and non-failed firms. The information content of operating cash flow is found to add incremental discriminatory power to the prediction of UK company failure. Agarwal and Taffler (2007) adopt an altogether different approach, and run a logit model based upon the original Taffler (1983) z-score model, which they contrast with a loss-making firm predictive model. 
We start with a simple "pure" accounting based model along the lines proposed in Shumway (2001). Even though we show that we can improve upon that, by bringing in market-based values following Campbell et al (2008), we believe that such a model may have utility to those researching distress prediction in unlisted companies. For example, Peel and Peel (1987) investigate private company failure on a data set of 194 large UK industrial private companies. These firms are derived from the Extel Unquoted Companies Service which contains the information on the 2100 largest private companies in the UK with reference to turnover, a measure which is hardly representative of small firms in general. Their findings demonstrate that qualitative variables, such as the lag in accounts submission, have significant incremental information content and improve the prediction result. Such a model also facilitates comparison with earlier accounting-based UK models.

We go on to examine the impact of adopting market-defined values, as in Campbell et al (2008), and show that this leads to significant improvements in predictive power, both in-sample and out-of-sample, over the pure accounting model. We argue that it should be possible to improve such models further by incorporating macro-economic variables, and indeed show that that is the case. Last, we examine the impact of specifying industry level models. Chava and Jarrow (2004) show, that as would be intuitively expected, industry effects are important in predicting bankruptcy. When we include such effects we see a modest improvement in performance from so doing in the accounting, market and economic models, but a more significant improvement in the pure accounting model. 


\section{Research method and data}

We employ the "hazard", or "dynamic logit" model of Shumway (2001), Chava and Jarrow (2004) and Campbell et al (2008). As the latter acknowledge, this is a relatively atheoretical econometric approach. Whilst more theoretical approaches are available (for a summary see Christidis, 2010, Ch.2) the result is a fairly powerful model that uses publicly available data. We try and avoid problems of data mining by only employing variables found to be relevant in the previous literature, rather than adopting a "kitchen sink" approach, but also supplement the accounting variables by including macro-economic variables which theory would suggest should be relevant to predicting distress.

Specifically, we are interested in the most extreme form of financial distress, corporate failure. Of course, we acknowledge that our particular definition of financial distress suffers from being somewhat arbitrary (Keasey and Watson, 1991; Balcaen and Ooghe, 2006), and that other forms of distress are worthy of study. As Agarwal and Taffler (2007, p.288) note, there are alternative events, such as restructurings, that can result in severer losses to equity holders and debt holders. However, we follow them in selecting measures of insolvency that are "clean". For our purposes, we define failure as one of the following types of death classified in the London Share Price Database (LSPD): (1) Suspension or cancellation with share acquired later (2) Liquidation (usually valueless, but there may be liquidation payments) (3) Quotation suspended - if suspended for more than three years, this may lead to automatic cancellation (4) Voluntary liquidation, where value remains and was/is being distributed (5) Receiver appointed/liquidation. Probably valueless, but not yet certain (6) in Administration or administrative receivership (7) Cancelled and assumed valueless.

Our sample consists of most liquidations and receiverships that occurred in the U.K. between 1978 and 2006 among publicly listed companies. For ease of exposition, we refer to firms that go into receivership or are liquidated by the shorthand of "bankrupt" firms, although legally in the UK whilst individuals can go "bankrupt" limited companies cannot. Whilst some may view such shorthand as irredeemably sloppy, nonetheless "bankruptcy" is a convenient term that is internationally understood. The total number of bankruptcies included in this expanded database is 
589 initially. Our total number of non-bankrupt firm-years is 49,063 and our average "bankruptcy" rate is $1.19 \%$. We include listed firms from all industries, with the exception of banks, insurance companies and investment trusts, while retaining all other general financial companies in the finance sector which differentiates our study from others that commonly use only industrial firms. We also exclude secondary stocks of existing firms and foreign stocks. We include Alternative Investment Market (AIM) companies in our study. We exclude Investment or Financial Trusts as they are often voluntarily liquidated after a few years or terminated upon agreement. A summary of the number of events for each category is given in Table 1. The sample is, we believe, by far the largest sample of such events in any UK study. For example, Agarwal and Taffler (2007) have 232 firm years matched with a sample of 27,011 non-failed firms.

Chava and Jarrow (2004, p.546-8) show that under non-informative censoring ${ }^{1}$, a standard logistic model of the form:

$$
P_{t}^{i}=1 / \mathbf{I}+\exp \leftarrow \alpha_{t}-\beta^{\prime} X_{i t}=
$$

where $X_{i t}$ are the time-varying co-ordinates (accounting, market and macroeconomic variables), can be estimated. We estimate our models using the logistic regression function in Stata.

In setting up the model, we follow Chava and Jarrow (2004) and set the dependent variable equal to one in the year of liquidation and to zero otherwise. A firm contributes an observation in the estimation equation for each year from the firm's Start Date, taken from the LSPD, until the end of the observation period or until it dies. A firm that is delisted for any reason other than those listed in Table 1 (e.g. it is acquired) would contribute observations until the delisting year. The liquidation year is defined as the calendar year of the Death Event Date as given in LSPD. For firms that go into liquidation within three months of their fiscal year-end, it is assumed that the most recent year's financial statements are not available and the prior fiscal year is defined as the year before bankruptcy. We find that the average lead time between the date of the fiscal year of the last relevant report and bankruptcy is quite long,

\footnotetext{
1 "Non-informative" means that the censoring point (e.g. due to a firm disappearing from the dataset because of a merger) is independent of the failure point.
} 
approximately thirteen to fifteen months. Lennox (1999) also found that the average length of time between the final annual report of a failing company and its entry into bankruptcy is fourteen months, which is consistent with the findings of Citron and Taffler (1992), and Agarwal and Taffler (2007). Schwartz and Menon (1985) suggest that failing firms are likely to delay the submission of their accounts. Keasey and Watson (1988) also find that it is not uncommon for the accounts relating to the 2-3 years prior to bankruptcy never to be produced or to be unavailable after bankruptcy occurs.

Beaver (1966) adopted the use of financial ratios in bankruptcy prediction and established that they have predictive power up to at least five years prior to bankruptcy. Previous studies show that the bankruptcy prediction models generally focus on areas such as profitability, liquidity, cash flow generation, and leverage. Some researchers (Argenti, 1976; Slatter, 1984) have identified a number of symptoms of decline that can be picked up from a company's financial statements. These may include declining profitability, decreasing sales at a constant price, increased borrowing, a decline in liquidity, a cut in dividends to conserve cash, the use of creative accounting, changes in auditor, increasing delays before accounts are published, rapid management turnover, declining market share, lack of planning, and a paralysis of management decision making.

Beaver et al (2005) emphasise that when selecting predictor variables, one should take into account the development of accounting standards, the increase in the relative importance of intangible assets and financial derivatives, and the perceived increase in the degree of discretion entering financial statements. Keasey \& Watson (1991) also suggest that the models based on data from earlier time periods need to be used with care, as there is an extensive institutional change in the early period. In the UK, for example, the 1980s was a decade when a number of important changes took place, such as financial deregulation, an upsurge in corporate restructuring activities, such as buy-outs, privatizations, mergers, takeovers, etc, and the passing of the 1986 Insolvency and Disqualification of Director Acts. Taffler (1982) also suggests that the dramatic changes in the UK economy and major changes in the system of company taxation would highlight the need to monitor the performance of the models continuously to ensure that reasonable degrees of population stationarity and stability 
in the underlying relationships continue to hold. We deal with this issue by conducting out-of-sample tests for each of our models. If changes of the nature discussed pose a problem for UK models, then we should see poor out-of-sample predictive power when we use earlier periods to predict later periods. In fact, it appears that the inclusion of market variables and economic variables is capable of overcoming any difficulties posed by such environmental and accounting standard changes.

\section{Selection of candidates for predictive variables}

A careful selection of predictor variables is needed, not only to improve the predictive performance of bankruptcy prediction models (Karels ad Prakash, 1987), but also to ensure that our variable selection process is guided by theory. We first group the accounting variables into a number of categories, and explain why these categories are selected. We then present summary statistics on those variables found to have the best predictive power in Tables 2 and 3 .

\section{Liquidity}

Liquidity reflects the ability of the firm to meet its short term commitments and the potential to generate working capital funds. (i.e. current ratio, working capital/total assets). The ratios would be expected to be critical immediately prior to failure, since only liquid assets can generate cash to cover obligations. Over the long-run, firms may try to minimise liquidity in order to channel funds into productive assets. Overcommitment of funds to investment or inadequate anticipation of upcoming needs for liquidity may easily precipitate a crisis (Zavgren, 1985). The quick or acid test ratio is applied to examine whether a company has adequate cash or cash equivalents to meet its current obligations without having to resort to liquidating non-cash assets such as stocks.

\section{Profitability}

Most studies suggest that profitability has important influence, since companies with low profitability are likely to become less liquid and more highly geared (Morris, 1997). We initially choose variables to reflect the strength of the company's profitability at different stages of its earning process, such as net income, earnings before interest and tax, and retained earnings. This helps to identify whether the earnings are sensitive to changes in a firm's operating health. Gupta (1983) shows that almost every company failure has been preceded by a period of impairment of 
earnings. When earnings are impaired, the supply of funds also soon dries up, affecting both working capital for current operations and long-term capital for growth. Taffler (1982) showed that profitability and financial leverage have a higher contribution in predicting financial distress, whereas the lack of working capital and short-term liquidity are of less importance in magnitude to liabilities and earnings abilities.

Cash flow

Although cash flow reporting has been recognised as important in the UK in the past decade, an examination of the existing UK failure literature reveals that operating cash flow variables have not been yet been widely examined in UK insolvency models. Prior US studies provided some evidence that operating cash flow-related variables may add to the explanatory power of bankruptcy prediction models (Casey and Bartczak, 1984 and Gentry et al, 1985). Beaver (1966) carried out a univariate study of 30 ratios and concluded that cash flow to total debt is the best single ratio predictor. Lennox (1999) suggested that default on debt servicing often increases the chance of bankruptcy, especially if the firm does not have relatively easy access to internal or external finance. This reflects a higher likelihood of a firm to go bankrupt if it has cash flow problems, compared to a firm which has easier access to its internal finance.

\section{Leverage}

The long term financial position of the firm is reflected in its leverage, which determines the ability of the firm to meet its debts in the long run and the ability to raise new capital through borrowing (i.e. total liabilities/total assets, long-term debt/net capital employed). A major concern is whether the firm can service its debts or generate enough profit to be able to pay the interest on its loans. Leverage ratios measure the extent to which the assets are covered by liabilities and the extent to which assets can depreciate in value and still meet its commitments with regard to external debt or borrowed funds. If the firm is heavily dependent on borrowed funds, profits will be high during years of growing profitability, but in a bad year, they will be low or negative. Leverage ratios therefore indicate the level of financial risk in addition to the business risk a firm might face.

\section{Activity and Company Characteristics}

Activity ratios measure how effectively a firm is exploiting its assets. They could also indicate whether a firm is keeping adequate levels of assets, which could in turn affect 
its performance in the long run. Some other activity ratios related to creditors and debtors indicate the effectiveness of a company's credit policies, the demand for its products and can also reflect to an extent whether the firm is having difficulties in meeting its obligations. Company characteristics, such as size and age, could identify the strength and weakness of the firms to survive through the different phases of their business cycle.

\section{Market Variables}

Prior research has examined the ability of variables based on market values to predict bankruptcy (Hillegeist et al, 2004, Chava and Jarrow, 2005, Shumway, 2001). Market price is a useful indicator that incorporates the information learnt from financial statement data released by the firm as well as other information available in the market. Rees (1995) provides support for the idea that market price can be a valuable predictor of failure, even if it is influenced by other factors. He suggests that market price not only reflects a wide variety of information related to the expected future cash flows but it also reveals a subset of information about the likelihood of liquidation and cash flow impact. Thus, a sharp fall in the market price or unusual market-based ratios might be viewed as a warning. The large body of empirical evidence implies that incorporating market data into the models is likely to provide substantial benefits, particularly with respect to timeliness of information (Keasey and Watson, 1991). In the UK, full accounting data are only available annually with interim financials available semi-annually, but only quarterly in some limited cases. Market price variables give more timely information and also provide a direct measure of volatility. The market-based variable most typically used in prior research is the firm size measured by market capitalisation.

Beaver et al (2005) suggest that the probability of bankruptcy may be embedded in the market price, even though it may not be a direct measure of that probability. They note that (p.110) "as the probability of bankruptcy increases, the nonlinear nature of the payoff function for the security becomes increasingly more important because of risky debt and limited liability". Hillegeist et al (2004) argue that the conservatism principle in accounting methods might cause asset values to be understated relative to their market values, particularly for assets and intangibles. They conclude that (p.6) "downward-biased asset valuation might cause measures of accounting-based leverage to be overstated". Beaver et al (2005) point out that the market-to-book ratios 
may also serve as a crude approximation of the relative importance of intangible assets, which has gradually increased over time as research and development expenditures have become important in technology-based firms.

Many recent studies have introduced the measure of asset volatility as another crucial variable in bankruptcy prediction. Hillegeist et al (2004) suggest that volatility captures the likelihood that the value of the firm's assets will decline to such an extent that the firm will not be able to repay its debts. The probability of bankruptcy is perceived to increase with volatility. Two firms with identical leverage ratios may have substantially different probability of bankruptcy depending on their asset volatilities. Lys (1984) found that when the leverage ratio is used as a single proxy for financial risk, volatility becomes important and is highly correlated with the leverage ratio. Campbell et al (2001) also point out that the absence of any volatility measure in the accounting-based models is likely to lead to a substantial reduction in their performance, as firms exhibit considerable cross-sectional variation in volatility.

\section{Economic variables:}

Whilst it seems intuitive to include macro-economic variables in a bankruptcy prediction model, one can reasonably argue that such variables should be redundant in a model that incorporates market price information, as market values should fully embed all available information. However, it is possible that leading indicators can add to information in prices insofar as market prices reflect expected cash flows and discount rates, whilst economic variables may tell us something about downside risk, which is of key importance in bankruptcy prediction models. We employ the market timing variables proposed by Gregory (2000) as the economic indicators in our model. The change in the return of FTSE All Share Index over the previous twelve months (DMKT) is employed as the first business cycle variable. As the levels of interest rates and inflation rates in the economy are likely to affect the firm differentially according to its choice of financing method, we incorporate a proxy for interest rates (TBR) into the model represented by the nominal three-month Treasury Bill Rate. The monthly change in Retail Price Index is also incorporated as a measure of the inflation rate (INFL). An inverted yield curve can be useful recession indicator, so we include the term structure premium, which is the difference between long-term gilt rate and Treasury Bill Rate (LONGSHT). Two direct measures of economic 
activity are also used. The first is the 12-month change in the UK Long Leading Indicator published by the National Statistics Office (CUKLEAD). The second is the monthly change in the Industrial Production Index (INDPROD). All the raw data required for the calculation of the variables are obtained from Datastream and LSPD. As an alternative measure of interest rates, we calculate a deflated Treasury Bill rate, (DEFLTBR). However, our analysis shows that only interest rate variables and inflation, in conjunction with INDPROD add explanatory power to the models based upon accounting and market variables.

Following the procedure suggested by Cohen, Polk, and Vuolteenaho (2003) and Campbell et al (2008), we also adjust the book values of assets to eliminate outliers. We add $10 \%$ of the difference between market and book equity to the book value of total assets. This leads to an increase of book values that are extremely small, which may not be properly measured and may generate outliers when used as the denominators of financial ratios. We calculate the monthly log excess return on each firm's equity relative to the FTSE All Share Index (EXRET), the standard deviation of each firm's monthly stock return over the past six months (SIGMA), and the relative size of each firm measured as the log ratio of its market capitalization to that of the FTSE All Share Index (RSIZE). We also take each firm's price per share from LSPD (PRICE). We attempt to further limit the influence of outliers by Winsorising all the variables in our model at the $5^{\text {th }}$ and $95^{\text {th }}$ percentiles of their pooled distributions across all firm-year observations. We replace any observation below the $5^{\text {th }}$ percentile with the $5^{\text {th }}$ percentile, and any observation above the $95^{\text {th }}$ percentile with the $95^{\text {th }}$ percentile. This adjustment also applies to those firms whose book equity has been adjusted as above.

From the potential candidate list, an extensive univariate analysis ${ }^{2}$ and the testing of alternative logit models, we end up with the following list of variables which we include in the first logistic regression, "the accounting model": working capital over total assets (WCTA); total liabilities over total assets (TLTA); cash flow over total assets (CFTA); change in net income (CHIN); following Ohlson (1980), a dummy variable equal to one if net income was negative for the last two years (INTWO);

\footnotetext{
${ }^{2}$ Not reported here for reasons of space, but available from the authors on request.
} 
earnings before interest and tax over share capital (EBITSHARE); quick assets over current assets (QACA); and funds from operation over total liabilities (FOPTL). For the accounting model we end up with a sample of 558 bankrupt firms for which we can obtain sufficient information to calculate all the above variables. Summary statistics on these variables are presented in Table 2. We show separately the characteristics of liquidated, non-liquidated and acquired firms, as a number of previous studies (Shrieves and Stevens 1979; Pastena and Ruland 1986; Peel and Wilson 1989; and Peel 1990) have examined the possibility of a merger/bankruptcy alternative to financial distressed firms. Their studies indicated that a significantly large minority of merged firms, around 15-17 percent, exhibited symptoms of financial distress in the year prior to merger compared to the general population of firms, where less than 5 percent were defined as distressed. Peel (1990) suggested that it is usually the distressed firms which actively seek a partner.

Panel A of Table 2 describes the distribution of the variables in the entire dataset, panel B describes the properties of the bankrupt group, panel $\mathrm{C}$ describes the nonbankrupt group, and panel D describes the firms that were either merged or acquired. A comparison between panel A and B reveals that firms that go into liquidation have some differences from the rest of the sample which are intuitive. All the explanatory variables appear to have a lower and poorer performance in the liquidated group compared to other groups. The liquidity of the bankrupt firms, as reflected in the working capital ratio WCTA, is significantly lower than the non-bankrupt firms. The mean value for liquidated firms is only $7.1 \%$, while for the non-liquidated firms it is $17 \%$. The median is also has a much lower at only $3.9 \%$. The value of the TLTA is fairly high relative to the assets with the average leverage at $61.8 \%$ and the median leverage in excess of $66 \%$. Liquidated firms appear to experience negative cash flows and a greater propensity to have negative earnings in consecutive years prior to bankruptcy. Funds flow and profitability measures are also significantly negative, for example FOPTL is $-14.1 \%$ as compared to $24.7 \%$ in the acquired group and $17.6 \%$ in the non-liquidated group. EBITSHARE is also negative for the liquidated group but positive for the rest of the sample. The acquired firms group has stronger cash flow and profitability components despite the slightly lower liquidity in quick asset and working capital compared to the rest of the non-liquidated firms. The standard deviation of the explanatory variables is consistently higher in the bankrupt group 
compared to the rest, whereas those of the acquired group are consistently lower across all the variables.

Table 3 displays the characteristics of the variables for the market and accountingbased model. Missing price or returns data mean that the sample for this analysis is limited to 428 bankrupt firms. Variables are: total liabilities over market value of equity (TLME); log excess return over FTSE All Share Index (EXRET); cash flow over market value of total assets calculated by addition of firm market value and book value of total liabilities (CFMTA); standard deviation of firm stock returns over the previous six-month period (SIGMA); price per share (PRICE); net income over market value of total assets (NIMTA); total liabilities over adjusted total assets calculated by adding $10 \%$ of the difference between market equity and book equity (TLTADJ); and log of firm's market equity over the total valuation of FTSE All Share Index (RSIZE). Again we see that the bankrupt firms have a relatively much higher leverage. The value of their debts is extremely high compared to the market value of equity or the total adjusted assets value. The average TLME is 2.542 as compared to 0.999 for non-bankrupt firms, including acquired firms. The bankrupt firms typically make losses and have a mean net income of $-5.6 \%$ relative to the market value of their assets. The bankrupt firms also experience negative excess returns with a mean value of $-14.5 \%$, which is close to the median value of $-14.9 \%$. The bankrupt firms typically have a much lower price per share. The mean price per share is only $24 \mathrm{p}$ for bankrupt firms, while the median price per share is only $7 \mathrm{p}$. The firm size is also smaller than that of the non-bankrupt firms. Their volatility has a mean six-month SIGMA of $25.5 \%$ and a median SIGMA of $22.3 \%$, which are considerably higher than the rest of the sample.

Table 4 summarises the variables for the accounting, market, and economic-based model (henceforth the AME model). Variable values for the market and accounting based variables are as Table 3 values. We can see that bankruptcy seems to be associated with times when the economic outlook is unfavourable, as proxied by the yield curve, with a mean LONGSHT of $-0.25 \%$, whereas non-bankruptcy is associated with a LONGSHT value of $0.127 \%$. LONGSHT is higher still for the acquired firm group at $0.182 \%$. INFL remains at a similar level with mean and median close to $0.44 \%$ across the groups. However, there is a slightly higher monthly 
inflation rate amongst the failed firm group. TBR seems to be fairly stable across the groups with a mean of $8.2 \%$ and a median of $7.0 \%$. The bankrupt group has a higher mean of $8.4 \%$, a similar median, and a higher standard deviation. However, the acquired firm group has a higher mean of $9.2 \%$ and a median of $9.4 \%$.

\section{Results}

The results from running the logistic regressions for each of our models are presented in Tables 5-7. We start with the pure accounting model, which as we note above requires no market data and may, therefore, be applicable to unlisted firms (although we stress that we do not test it on such firms).

Table 5 reports the logistic regression results for this accounting model. Eight variables are found to be significant at the $1 \%$ level and all have the expected sign: WCTA, TLTA, CFTA, CHIN, INTWO, EBITSHARE, QACA, and FOPTL. These variables reflect a combination of different aspects of the firm's health which can be used to predict bankruptcy. Profitability is clearly important category with three significant variables (CHIN, INTWO and EBITSHARE). It is followed by liquidity with two variables (WCTA and QACA), cash flow and funds-flow (CFTA and FOPTL), and leverage as measured by TLTA.

Five variables from the Ohlson's (1980) O-score model are found to be significant in our accounting model. One of them is WCTA, which has been found to be highly significant in a number of bankruptcy studies and is one of the main variables in Altman's used Z-score model. TLTA has a positive sign, showing that higher leverage leads to a higher risk of bankruptcy. The negative sign of CHIN and positive sign of INTWO indicate that the deteriorating losses in past earnings lead to a greater likelihood of financial distress. The negative sign of FOPTL also indicates that lower funds provided by operations to cover the total debts increase the chances of bankruptcy. QACA has a weak correlation to WTCA and acts as an indicator of the firm's short term financial stability, assessing whether the firm can convert assets into cash fairly easily in the immediate near future if any financial needs arise. EBITSHARE has a negative sign and shows that the declining earning ability of the firm before its interest and tax obligations as compared to the value of the firm equity give a signal that the firm might be in trouble. Lastly, CFTA raises the firm's 
attention to its cash flow generating ability even in time when the firm has fair profitability performance.

We check the collinearity diagnostics for all these variables since high correlation might lead to imprecise estimates of the regression coefficients or increasing standard errors, thus compromising to some extent the tests of significance. All the variables have a low variance inflation factor (VIF) and high tolerance. However, whilst the model is statistically significant, and the area under the ROC (Receiver Operating Characteristics) curve is a reasonable $81.24 \%^{3}$, the Hosmer and Lemeshow (2000) $\chi^{2}$ test (hereafter the HL test) for goodness-of-fit suggests that the model does not fit the data well. ${ }^{4}$ This further motivates the use of market and/or macro-economic variables.

\section{The Accounting and Market Model}

We replace the traditional accounting ratios NITA and TLTA that use the book value of assets with the market-based series from Campbell et al (2008). These measures are more sensitive to new information about firm prospects since equity values are measured using monthly market data rather than annual accounting data. Despite the fact that the market-to-book ratio is significant in the univariate analysis, it is not significant in the multivariate model, in contrast to the findings of Campbell et al (2008). Accordingly, we try estimating an alternative model, the Accounting and Market Model (1). In this model, we employ both the book value of total liabilities to market value of equity (TLME) and liabilities to total adjusted assets (TLTADJ), both of which turn out to be highly significant. The correlation between TLME and TLTADJ is 0.3055 which is within acceptable bounds. The first measures the total leverage over market value of equity, while the second measures the leverage relative to the total adjusted assets employed by the firm (at market values for the equity element). The likelihood test between the full model and restricted model, in which either TLME or TLTADJ is dropped, shows that keeping both variables gives a better

\footnotetext{
${ }^{3}$ A useful discussion of ROC curves can be found in Agarwal and Taffler (2008b).

${ }^{4}$ In this respect, note that although Agarwal and Taffler (2007) do not report HL test results, their zscore model is capable of generating some extreme predictions. As they note (p. 288-289) their model predicts the percentage of firms "at risk" (i.e. with negative z-scores) ranges from $14 \%$ in 1979 to a peak of $43 \%$ in 2002. The actual percentage of firms that failed in those two years in our sample was $1.27 \%$ and $2.55 \%$ respectively. This suggests their model is capable of generating a very high Type II error rate.
} 
prediction. The rest of the market variables in Campbell et al's (2008) model enter the logit regression with the expected sign and are highly statistically significant at the $1 \%$ level, although RSIZE is only significant at the 5\% level. A negative sign on EXRET shows that firms earning lower returns than the market return have a higher risk of going bankrupt, and the coefficient on SIGMA shows that high volatility is associated with an increased probability of bankruptcy. Firms with a lower market price per share and a smaller market capitalisation relative to the market are more likely to go bankrupt. Finally, NIMTA has a significant negative coefficient, suggesting that a low level of profitability measured relative to market values of total assets is an indicator of financial distress.

In the second Accounting and Market Model (2), the book-to-market ratio enters as significant variable when we include the WCMTA ratio, which was also significant in the pure Accounting Model in book value terms. As would be expected, the sign of the coefficient on WCMTA is negative. The coefficient on the book-to-market ratio is consistent with "value" stocks having a higher probability of going bankrupt. The correlation of both ratios to the rest of the variables remains low, apart from the correlation between the book-to-market ratio and TLMTA, which is 0.5712, an acceptable tolerance level.

It is clear that the predictability of the models improves as we add market and marketadjusted variables into the model. The R-squared improves significantly from $12.73 \%$ to approximately $25 \%$ in both market variable based models and the area under the ROC curve also increase from $81.24 \%$ to $89.92 \%$ and $89.61 \%$ in models 1 and 2 respectively. Testing the differences between the two Market Models, a likelihood ratio tests show that the second Market Model does not have superior predictive ability, as does a simple comparison of the R-squared and area under ROC curve figures. The HL tests show that both models fit the data well.

\section{The effects of adding macro-economic variables}

In Table 7, we report results from two logit regressions with the inclusion of macroeconomic variables, our AME Models. For comparison, we repeat the results from our marginally-preferred accounting and market model (Model 1) in the first two columns of the Table. We can see that the inclusion of economic variables slightly 
changes the candidate market and accounting variables, with TLMTA being preferred as the measure of leverage rather than TLME and TLTADJ. Coefficients change slightly for the common variables, with most generally having stronger explanatory power. In AME Model 1, the yield curve measure (LONGSHT) and the Treasury Bill and Inflation rate are significant predictors of distress, whereas in AME Model 2 the real interest rate replaces the Treasury Bill rate as a significant predictor (albeit only at the $10 \%$ level) and decreases in the Industrial Production variable predict distress. Compared to the Accounting and Market Model, the R-squared of the AME Model (1) improves from $25.33 \%$ to $26.22 \%$ and the ROC curve area increases from $89.92 \%$ to $90.34 \%$. A likelihood ratio test confirms a highly significant increase at the $1 \%$ level in the predictive ability of the model relative to the Accounting and Market Model. Our second AME Model (2) also records a highly significant increase in predictive power relative to the Accounting and Market Model, although ROC area under the curve and R-squared statistics are marginally lower than those from Model 1. HL statistics confirm that both models have good predictive abilities.

In Table 8, we re-estimate the model after excluding 30 observations with unusual residuals. We identify the observations that fit poorly and those that have a great deal of influence on the values of the estimated parameters by utilising the regression diagnostics (Pregibon, 1981) and graphical analysis suggested in Hosmer and Lemeshow (2000, p.177-180). These are plotted by utilising the predict residuals, hat, dbeta and $d x 2$ options within Stata. Of course, one can object to such a process on the grounds that it involves another layer of "data snooping", but several of the companies involved were clearly unusual and some had a certain notoriety (to name but two, British and Commonwealth Holdings; Maxwell Communications). The first effect is to change the significance of some of the macro variables. In AME Model 1, INFL is now only significant at the $10 \%$ level. In AME Model 2, the deflated interest rate measure now becomes significant at the 5\% rather than the $10 \%$ level. Both models and the Accounting and Market Model show a substantial improvement in the explanatory power of the sample.

\section{Goodness-of-Fit Tests}

In this section, we analyse the predictive ability of AME Model (1), which has marginally more predictive ability than the second version of the model. The Hosmer- 
Lemeshow statistic reported in Table 9 suggests that the observed and expected values in each decile are close and the model passes the significance test at the $1 \%$ level. We next undertake a test of the model's out-of-sample predictive power. To do this, we partition our sample into a period 1978-1991, and 1992-2006. We first re-estimate our model using data from the period 1978-1991 only, and use this to predict bankruptcies in 1992. We then roll this experiment on by one year, using 1978-92 to predict 1993 bankruptcies, and so on until finally the model is estimated on the basis of 1978-2005 data to predict 2006 bankruptcies. Table 10 then reports the forecasting accuracy of the in-sample and out-of-sample performance of the model. For the insample test, the model can predict $99.30 \%$ of the bankrupt firms correctly in the 5 deciles with the highest probability of bankruptcy. Looking at the two highest probability deciles, the model predicts $89.7 \%$ correctly. The model reports only $0.70 \%$ of the firms as misclassification in the lowest 5 deciles of probability, and this compares to $3.60 \%$ for Accounting and Market Model (1) and 3.27\% for Accounting and Market Model (2). ${ }^{5}$

The forecasting ability of the out-of-sample performance increases slightly to $99.55 \%$ for the five deciles with the highest probability of bankruptcy. The misclassification for the low 5 probability deciles is $0.45 \%$, which is lower than $2.79 \%$ for the Accounting and Market Model (1) and the 2.36\% in Accounting and Market Model (2). The two highest probability deciles can predict $91.52 \%$ of the bankrupt firms correctly. The other AME Model (2) shows similar results, but Model (1) has the edge in terms of out-of-sample performance.

Finally, following Ohlson (1980), in Table 11 we show that the cut-off point that minimises the sum of errors is .0092 . At that point, $10.30 \%$ of the bankrupt firms and $18.11 \%$ of the non-bankrupt firms are misclassified. The expected average error rate would then be $14.21 \%$. As a comparison with the Accounting and Market Model (1), the Type I error drops from $16.59 \%$ to $10.30 \%$ whereas the Type II error drops from $18.58 \%$ to $18.11 \%$. Of course, minimising the error in this way makes the almost certainly wrong assumption that the cost of Type I and Type II errors is equal, and a

\footnotetext{
${ }^{5}$ Full results available from the authors on request.
} 
more complex analysis of the costs and benefits of alternative error types can be found in Agarwal and Taffler (2008b).

\section{Prior year estimates}

In this section, we discuss logistic regression models using data from prior years. Previous researchers have found that bankruptcy models generally show a decline in accuracy for more distant bankruptcy horizons (Lennox, 1999; Campbell et al, 2008). We estimate the conditional probabilities of bankruptcy with a two-year and threeyear horizon. In the logit specification, the coefficients are allowed to vary with the horizon of the prediction. The probability of bankruptcy in $j$ years, conditional on survival in the dataset for $j-1$ years, is given by (Campbell et al, 2008 p. 2912 equation [4]):

$$
P_{t-1} \bigotimes_{i, t-1+j}=1 \mid Y_{i, t-2+j}=0 \lesseqgtr 1 /\left(+\exp \mid \alpha_{j}-\beta_{j} x_{i, t-1}\right.
$$

The coefficients, significance levels, and overall fit of the logit regression decline as the horizon increases. At the two year horizon, all the variables remain statistically significant, but the R-squared falls to $13.35 \%$ and the area under the ROC curve to 81.79\%. At the three year horizon, EXRET, SIGMA and LONGSHT all lose statistical significance, although intriguingly all the variables that embed accounting numbers do not. This rather strengthens the case that Agarwal and Taffler (2008b) make for "unfashionable" financial statement based models as opposed to optionbased models. Last, and fairly obviously, explanatory power falls, with R-squared being only $9.29 \%$ and the area under the ROC curve falling to $77.44 \%$.

\section{Adding Industry Effects}

In the unreported tests, ${ }^{6}$ we find that the forecasting ability of the Accounting, Market, and Economic Model (AME) appears to differ across ten different industry groups. In this section, we follow the approach of Chava and Jarrow (2004) and test for industry effects by fitting the AME model with intercept and slope coefficient dummy variables for each industry grouping. Initially, we conduct simple t-tests to check whether variables found to be significant in the AME model vary across industry groups. Those tests help inform our choice on which predictor variables should be included in the industry model with slope-shifting dummies. For example, it is clear

\footnotetext{
${ }^{6}$ These are unreported for space reasons, but available from the authors on request.
} 
that none of the macro-economic variables or the price, market capitalisation or sigma variables show significant cross-sectional variation across industries. In their approach, Chava and Jarrow (2004) combine the industry classifications into smaller groups because they suggest that their original partitioning might be too fine for estimation purposes. In a similar fashion, we combine the industry classifications into five groups. The five industry groups we select are: (1) Manufacturing: Industrials and Consumer Goods; (2) Services: Consumer Services, Healthcare, Telecommunication, Utilities; (3) Financials; (4) Technology; and (5) Oil \& Gas and Basic Materials.

Table 12 reports the results from logit regressions of the bankruptcy indicators on predictor variables for the AME model with the inclusion of industry effects. The slope dummy variables are applied to TLMTA and NIMTA in this model. ${ }^{7}$ The base case is IND1, so that dummies are capturing variation compared to the Manufacturing industry. Consistent with Chava and Jarrow (2004), not all the industry variables are significant in the model. TLMTA*IND2 and TLMTA*IND4 are significantly negative, indicating that Service and Technology industries are less exposed to leverage effects than manufacturing, while NIMTA*IND2 is significantly positive which suggests that Service industries are less vulnerable to poor profitability than their manufacturing counterparts. However, the industry dummy for services (IND2) is positive, indicating that despite the mitigating effects with regard to profitability and leverage discussed above, firms in the service sector have a higher baseline probability of bankruptcy. Finally, a test for the joint significance of all the industry and slope-shifting industry dummies confirms that we can reject the null hypothesis of joint insignificance.

Compared to the AME model without industry effects in Table 8, the R-squared of the model improves from $31.37 \%$ to $32.12 \%$, and the area under the ROC curve also increases from $93.40 \%$ to $93.58 \%$. A likelihood ratio test between the Constrained and Unconstrained Model indicates that the industry effect is significant at the $1 \%$ level. In Table 13 we show that the model provides a modest improvement in both its

\footnotetext{
${ }^{7}$ Note that we also estimate industry versions of the Accounting, and Accounting and Market models, not reported here as they are dominated by the AME model. In those models, the significant slopeshifting dummies on the predictor variables vary. Full results are available from the authors on request.
} 
in sample and its out-of-sample forecasting ability compared to the model without the industry variables. Comparing the results in Columns 1 and 2 of Table 13 the insample performance increases by $0.81 \%$ in the high probability decile and $0.56 \%$ in the highest 2 deciles. The misclassification error in the highest probability 5 deciles decreases from $0.70 \%$ to $0.65 \%$. With respect to the out-of-sample performance, the predictive ability in the highest decile increases by $1.13 \%$ and by $0.96 \%$ in the highest 2 deciles. The overall predictive ability in the five high probability of bankruptcy deciles increases by $0.13 \%$.

In unreported tests, we investigate whether industry effects improve the performance of the Accounting and Market, and the pure Accounting model. Both the in-sample estimation and out-of-sample prediction of all three models confirm the importance of industry effects. For prediction based on the AME Model and A\&M Model, the industry effects appear to be relatively marginal, almost certainly due to the inclusion of the market and economic variables. However, industry effects appear to be more important in the pure Accounting Model. For that reason, for the benefit of those researchers who are interested in models based purely on financial statements we present the model with industry effects in the Appendix.

\section{Conclusion}

Recent evidence in Agarwal and Taffler (2008b) highlight the fact that accountingbased models have an important role to play in the prediction of financial distress. They note that whilst accounting ratio based models are much criticised for a lack of theoretical grounding, they are capable of out-performing their more theoretically appealing contingent-claims based alternatives. They point out three factors that might favour accounting models: first, corporate failure is likely to evolve over time and as such will be reflected in financial statements; second, the nature of double entry bookkeeping means that combining accounting information should overcome the effects of policy changes or "window dressing"; third, loan covenants are generally based on accounting numbers. It is interesting to note that this latter point is timely in relation to the current credit and economic crisis, whilst the first point is consistent with our evidence on prior year bankruptcy prediction.

\footnotetext{
${ }^{8}$ Conceptually, this is not dissimilar to the arguments advanced for residual income valuation models with clean surplus accounting.
} 
Agarwal and Taffler (2008a, 2008b) obtain their results using a long-established simple z-score model, and this underpins the logit model they estimate in Agarwal and Taffler (2007). However, there is evidence from Shumway (2001) and Chava and Jarrow (2004) that a "hazard" or "dynamic logit" model can considerably improve the predictive power of simpler models. Most recently, Campbell et al (2008) show that market variables might further add to the power of "traditional" prediction models. Last, Chava and Jarrow (2004) show that industry effects can add power to such models. Yet to our knowledge, no published papers have attempted to apply such enhancements to the problem of bankruptcy prediction in the UK. This seems an important shortcoming, in at least three respects. First, it is unfortunate that the current economic environment has undoubtedly revived interest in financial distress prediction models. Second, recent work by Campbell et al (2008) shows that financially distressed firms deliver anomalously low returns. Unfortunately, without better distress prediction models we cannot be sure that this result holds in the UK, although Agarwal and Taffler (2008a) provide some interesting evidence in this regard. Last, Pope (2010) has raised the importance of financial distress indicators in the context of the asset pricing literature. To this end, well-specified models of financial distress would give a potentially useful input to new factor and portfolio construction.

These observations provide a strong motivation for a comprehensive re-visiting of bankruptcy prediction in the UK. Employing the Shumway (2001) and Chava and Jarrow (2004) "dynamic logit" model, we provide Accounting and Accounting and Market models for the UK. Following the logic of Campbell et al (2008), we extend their model by investigating the importance of macro-economic variables. We find that the risk free rate of interest, the term structure of interest rates, and an inflation term are significant variables in improving the basic Accounting and Market model of Campbell et al (2008). Extending the analysis further, by adding an industry effect as in Chava and Jarrow (2004) marginally increases the power of this model. However, industry effects seem more important in the context of a pure accounting model.

We do not interpret our results as in any way undermining the importance of accounting data. Rather, we see the results as emphasising the importance of 
combining accounting and market information. To a degree, this can be viewed as providing support for Pope's (2010) argument that accounting numbers can be informative about a firm's fundamental risk attributes. Our interpretation is in a similar sprit to that of Beaver et al (2005, p.112) who note "market-based variables are not a substitute for the accounting-based information but rather a proxy for the predictive power attainable by capturing the total mix of information, including both the financial statement and non-financial statement information." Three messages stand out for accounting research from our findings. The first is that financial statement information on profitability, cash flow and liabilities retain an important role in predicting distress even in the presence of market variables. Beaver et al (2005, p.115) argue that market-based variables do not distinguish between volatilities induced by business risk and financial risks, and our results are consistent with that claim. The second is that replacing accounting measures of book value with market measures in financial ratio denominators improves predictive power by making that information more timely. The third is that at longer forecasting horizons, it is only those variables that embed accounting information that retain any ability to predict financial distress.

Of course, as with any model of this type, we remain open to the accusation of "data mining". However, we note that we have been careful only to investigate those variables that have been found important in previous models, and many of these have been formulated outside the UK. Second, we have taken great care to validate our model by subjecting it to out-of-sample testing. Doing so reveals that the performance of the AME model in particular remains impressive.

\section{References:}

Agarwal, V. and Taffler, R.J. (2007), 'Twenty-five years of the Taffler z-score model: Does it really have predictive ability?', Accounting and Business Research, Vol. 37, No. 4, pp. 285-300. 
Agarwal, V. and Taffler, R.J. (2008a), 'Comparing the performance of market-based and accounting-based bankruptcy prediction models', Journal of Banking and Finance, Vol. 32, No. 8, pp. 1541-1551.

Agarwal, V. and Taffler, R.J, R.J. (2008b), 'Does financial distress risk drive the momentum anomaly?', Financial Management, Vol. 37, No. 3, pp. 461-484.

Argenti, J. (1976), Corporate Collapse; The Causes and Symptoms, McGraw Hill, Maidenhead.

Balcaen, S. and Ooghe, H. (2006), '35 years of studies on business failure: An overview of the classic statistical methodologies and their related problems', British Accounting Review, Vol. 38, pp. 63-93.

Beaver, W. (1966), 'Financial ratios as predictors of failure', Journal of Accounting Research, Vol. 4, pp. 71-111.

Beaver, W.H., McNichols, M.F., and Rhie, J. (2005), 'Have financial statements become less informative? Evidence from the ability of financial ratios to predict bankruptcy', Review of Accounting Studies, Vol. 10, No.1, pp. 93-122.

Campbell, J.Y., Lettau, M., Malkeil, B. and Xu, Y. (2001), 'Have individual stocks become more volatile: An empirical exploration of idiosyncratic risk', Journal of Finance, Vol. 56, No.1, pp. 1-43.

Campbell, J.Y., Hilscher, J. and Szilagyi, J. (2008), 'In search of distress risk', Journal of Finance, Vol. 63, No. 6, pp. 2899-2939.

Charitou, A., Neophytou, E. and Charalambous, C. (2004), 'Predicting Corporate Failure: Empirical Evidence for the UK', European Accounting Review, Vol. 13, No. 3, pp. 465-497.

Casey, C. and Bartczak, N. (1984), 'Cash-Flow-it's not the bottom line', Havard Business Review, August, pp. 661-666.

Chava, S. and Jarrow, R. (2004), 'Bankruptcy prediction with industry effects', Review of Finance, Vol. 8, No. 4, pp. 537-569.

Christidis, A.C. (2010), Bankruptcy Prediction in the UK and its Asset Pricing Implications, Unpublished PhD Thesis, University of Exeter.

Citron, D. and Taffler, R. J. (1992), 'The audit report under going concern uncertainties: An empirical analysis', Accounting and Business Research, Vol. 22, pp. 337-345.

Cohen, R. B., Polk, C. and Vuolteenaho, T. (2003), 'The value spread', Journal of Finance, Vol. 58, No. 2, pp. 609-641.

Gentry, J. A., Newbold, P. and Whitford, D. T. (1985), 'Classifying bankrupt firms with funds flow components', Journal of Accounting Research, Vol. 23, No. 1, pp. $146-160$. 
Gregory, A. (2000), 'Motives underlying the method of payment by UK acquirers: the influence of goodwill', Accounting and Business Research, Vol. 30, No. 3, pp. 227240.

Gupta, L. C. (1983), Financial Ratios for Monitoring Corporate Sickness, Oxford University Press, Oxford.

Hillegeist, S.A., Keating, E.K., and Lundstedt, K.G. (2004), 'Assessing the probability of bankruptcy', Review of Accounting Studies, Vol. 9, pp. 5-34.

Hosmer, D.W. and Lemeshow, S. (2000), Applied Logistic Regression, Second Ed., John Wiley \& Sons Inc., New York.

Karels, G.V. and Prakash, A.J. (1987), 'Multivariate normality and forecasting of business bankruptcy', Journal of Business Finance and Accounting, Vol. 14, No. 4, pp. 573-593.

Keasey, K. and Watson, R. (1986), 'Current cost accounting and the prediction of small company performance, Journal of Business Finance and Accounting, Vol. 13, No. 1, pp. 51-70.

Keasey, K. and Watson, R. (1988), 'The Non-Submission of Accounts and Small Company Failure Prediction', Accounting and Business Research, Vol. 73, No. 1, pp. 47-54.

Keasey, K. and Watson, R. (1991), 'Financial distress prediction models: a review of their usefulness', British Journal of Management, Vol. 2, pp. 89-102.

Ketz, J. (1978), 'The effect of general price level adjustments on the predictability of financial ratios', Journal of Accounting Research, Supplement, pp. 273-284.

Lennox, C. (1999), 'Identifying failing companies: a re-evaluation of the logit, probit and DA approaches', Journal of Economics and Business, Vol. 51, pp. 347-364.

Lys, T. (1984), 'Mandated accounting changes and debt covenants: The case of oil and gas accounting', Journal of Accounting and Economics, Vol. 7, pp. 39-65.

Mensah, Y. (1983), 'The differential bankruptcy predictive ability of specific price level adjustments: some empirical evidence', Accounting Review, Vol. 58, No. 2, pp. 228-246.

Morris, R. (1997), Early Warning Indicators of Corporate Failure, Ashgate, Aldershot.

Ohlson, J. (1980), 'Financial ratios and the probabilistic prediction of bankruptcy', Journal of Accounting Research, Spring, pp. 109-131.

Pastena, V. and Ruland, W. (1986), 'The merger/bankruptcy alternative', Accounting Review, Vol. 61, No. 2, pp. 288-301.

Peel, M.J. 1990, The Liquidation/Merger Alternative, Gower, Avebury. 
Peel, M.J. and Peel, D.A. (1987), 'Some further empirical evidence on predicting private company failure', Accounting and Business Research, Vol. 18, No. 69, pp. 5766.

Peel, M. J., Peel, D.A. and Pope, P. F. (1986), 'Predicting corporate failure-some results for the UK corporate sector', Omega International Journal of Management Science, Vol. 14, No. 1, pp. 5-12.

Peel, M.J. and Wilson, N. (1989), 'The liquidation/merger alternative', Managerial and Decision Economics, Vol. 10, No. 3, pp. 209-220.

Pope, P.F. (2010), 'Bridging the Gap between Accounting and Finance', British Accounting Review, Vo. 42, No. 1, pp. 88-102.

Pregibon, D. (1981), 'Logistic regression diagnostics', Annals of Statistics, Vol. 9, pp. 705-724.

Rees, B. (1995), Financial Analysis, Prentice Hall Europe, Hemel Hemptstead.

Schwartz, K. and Menon, K. (1985), 'Auditor switches by failing firms', Accounting Review, Vol. 60, No. 2, pp. 248-261.

Shrieves, R.E. and Stevens D.L. (1979), 'Bankruptcy avoidance as a motive for merger', Journal of Financial and Quantitative Analysis, Vol. 14, No. 3, pp. 501-515.

Shumway, T. (2001), 'Forecasting bankruptcy more accurately: a simple hazard model', Journal of Business, Vol. 74, No. 1, pp. 101-124.

Slatter, S. (1984), Corporate Recovery: Successful Turnaround Strategies and Their Implementation, Penguin, London.

Taffler, R.J. (1982), 'Forecasting company failure in the UK using discriminant analysis and financial ratio data', Journal of the Royal Statistical Society, Vol. 145, No. 3, pp. 342-358.

Taffler, R.J. (1983), 'The assessment of company solvency and performance using a statistical model: a comparative UK-based study', Accounting and Business Research, Vol. 15, No. 52, 295-307.

Taffler, R.J. (1984), 'Empirical models for the monitoring of UK corporations', Journal of Banking and Finance, Vol. 8, No. 2, pp. 199-227.

Zavgren, C. (1985), 'Assessing the vulnerability to failure of American industrial firms: a logistic analysis', Journal of Business Finance and Accounting, Vol. 12, pp. $19-45$. 
Table 1: Categories of Liquidation, Suspension and Receivership ("Bankruptcies")

\begin{tabular}{|c|c|c|c|c|}
\hline Code & Reasons & $\begin{array}{l}\text { LSPD } \\
\text { G10 }\end{array}$ & $\begin{array}{c}\# \text { of } \\
\text { Bankruptcies }\end{array}$ & $\begin{array}{c}\% \text { of } \\
\text { Bankruptcies }\end{array}$ \\
\hline 1 & Suspension & 6 & 10 & $1.70 \%$ \\
\hline 2 & Liquidation & 7 & 90 & $15.28 \%$ \\
\hline 3 & Quotation suspended & 10 & 24 & $4.07 \%$ \\
\hline 4 & Voluntary Liquidation & 11 & 36 & $6.11 \%$ \\
\hline 5 & Receiver appointed & 16 & 130 & $22.07 \%$ \\
\hline 6 & In Administration & 20 & 222 & $37.69 \%$ \\
\hline \multirow[t]{2}{*}{7} & $\begin{array}{l}\text { Cancelled \& assumed } \\
\text { valueless }\end{array}$ & 21 & 77 & $13.07 \%$ \\
\hline & Total & All & 589 & $100 \%$ \\
\hline
\end{tabular}

The table shows type of liquidation, suspension and receivership by LSPD Death Marker code, 1978-2006. 
Table 2: Summary Statistics for Accounting Model Predictor Variables

\begin{tabular}{|l|r|r|r|r|r|r|r|r|r|}
\hline Variable & WCTA & TLTA & \multicolumn{1}{c}{ CFTA } & CHIN & INTWO & EBITSHARE & \multicolumn{1}{c|}{ QACA } & FOPTL \\
\hline Mean & 0.169 & 0.479 & 0.051 & 0.039 & 0.111 & 0.152 & 0.702 & 0.172 \\
\hline Median & 0.152 & 0.479 & 0.056 & 0.071 & 0.000 & 0.154 & 0.700 & 0.193 \\
\hline St. Dev & 0.215 & 0.203 & 0.128 & 0.481 & 0.314 & 0.293 & 0.235 & 0.366 \\
\hline Min & -0.211 & 0.103 & -0.286 & -1.000 & 0.000 & -0.588 & 0.246 & -0.882 \\
\hline Max & 0.621 & 0.885 & 0.267 & 1.000 & 1.000 & 0.767 & 1.000 & 0.810 \\
\hline \multicolumn{8}{|c|}{ Panel B: Bankrupt Group } \\
\hline Mean & 0.071 & 0.618 & -0.043 & -0.255 & 0.288 & -0.006 & 0.702 & -0.141 \\
\hline Median & 0.039 & 0.663 & -0.019 & -0.248 & 0.000 & 0.013 & 0.729 & -0.041 \\
\hline St. Dev & 0.242 & 0.233 & 0.154 & 0.604 & 0.453 & 0.435 & 0.252 & 0.380 \\
\hline \multicolumn{8}{|c|}{ Panel C: Non-Bankrupt Group } \\
\hline Mean & 0.170 & 0.477 & 0.052 & 0.042 & 0.109 & 0.154 & 0.702 & 0.176 \\
\hline Median & 0.153 & 0.478 & 0.057 & 0.073 & 0.000 & 0.156 & 0.700 & 0.195 \\
\hline St. Dev & 0.215 & 0.202 & 0.127 & 0.478 & 0.312 & 0.291 & 0.234 & 0.364 \\
\hline & \multicolumn{8}{|c|}{ Panel D: Acquired Firms Group } \\
\hline Mean & 0.167 & 0.477 & 0.078 & 0.052 & 0.061 & 0.178 & 0.656 & 0.247 \\
\hline Median & 0.156 & 0.479 & 0.082 & 0.080 & 0.000 & 0.164 & 0.641 & 0.228 \\
\hline St. Dev & 0.196 & 0.179 & 0.106 & 0.452 & 0.239 & 0.240 & 0.228 & 0.295 \\
\hline
\end{tabular}

This table shows mean, median and standard deviation for the following variables: working capital over total assets (WCTA), total liabilities over total assets (TLTA), cash flow over total assets (CFTA), change in net income (CHIN), one if net income was negative for the last two years (INTWO), earnings before interest and tax over share capital (EBITSHARE), quick assets over current assets (QACA), and funds from operation over total liabilities (FOPTL). Panel A reports summary statistics for all firm observations, panels B and $\mathrm{C}$ report summary statistics for the bankrupt and non-bankrupt groups respectively, and panel D reports summary statistics for the acquired firms group (the censored component of the non-bankrupt firms). 
Table 3: Summary Statistics for Accounting \& Market Model Predictor Variables

\section{Variable TLME EXRET CFMTA SIGMA PRICE NIMTA TLTADJ RSIZE} Panel A: Full Sample

\begin{tabular}{|l|c|c|c|c|c|c|c|c|}
\hline Mean & 1.016 & -0.022 & 0.046 & 0.135 & 1.554 & 0.021 & 0.495 & -2.920 \\
\hline Median & 0.598 & -0.011 & 0.046 & 0.097 & 0.980 & 0.034 & 0.495 & -3.064 \\
\hline St. Dev & 1.121 & 0.123 & 0.081 & 0.114 & 1.619 & 0.060 & 0.233 & 1.831 \\
\hline Min & 0.047 & -0.341 & -0.139 & 0.029 & 0.010 & -0.152 & 0.048 & -5.952 \\
\hline Max & 4.327 & 0.185 & 0.200 & 0.472 & 5.860 & 0.100 & 0.975 & 0.721 \\
\hline \multicolumn{8}{|c|}{ Panel B: Bankrupt Group } \\
\hline Mean & 2.542 & -0.145 & -0.013 & 0.255 & 0.240 & -0.056 & 0.611 & -4.789 \\
\hline Median & 2.797 & -0.149 & -0.016 & 0.223 & 0.070 & -0.059 & 0.648 & -5.117 \\
\hline St. Dev & 1.686 & 0.180 & 0.109 & 0.157 & 0.517 & 0.085 & 0.269 & 1.236 \\
\hline \multicolumn{7}{|c|}{ Panel C: Non-Bankrupt Group } \\
\hline Mean & 0.999 & -0.021 & 0.046 & 0.133 & 1.571 & 0.022 & 0.493 & -2.899 \\
\hline Median & 0.591 & -0.011 & 0.047 & 0.096 & 1.000 & 0.035 & 0.493 & -3.042 \\
\hline St. Dev & 1.101 & 0.122 & 0.081 & 0.113 & 1.621 & 0.059 & 0.232 & 1.826 \\
\hline \multicolumn{8}{|c|}{ Panel D: Acquired Firms Group } \\
\hline Mean & 1.060 & -0.015 & 0.063 & 0.120 & 1.535 & 0.033 & 0.498 & -2.646 \\
\hline Median & 0.654 & -0.008 & 0.065 & 0.092 & 1.050 & 0.039 & 0.496 & -2.786 \\
\hline St. Dev & 1.105 & 0.112 & 0.075 & 0.098 & 1.487 & 0.048 & 0.206 & 1.625 \\
\hline
\end{tabular}

This table shows mean, median and standard deviation for the following variables: total liabilities over market value of equity (TLME), log excess return over FTSE All Share Index (EXRET), cash flow over market value of total assets calculated by addition of firm market value and book value of total liabilities (CFMTA), standard deviation of firm stock returns over a six-month period (SIGMA), price per share (PRICE), net income over market value of total assets (NIMTA), total liabilities over adjusted total assets calculated by adding $10 \%$ of the difference between market equity and book equity (TLTADJ), and log of firm's market equity over the total valuation of FTSE All Share Index (RSIZE). Panel A reports summary statistics for all firm observations, panels $\mathrm{B}$ and $\mathrm{C}$ report summary statistics for the bankrupt and non-bankrupt groups respectively, and panel D reports summary statistics for the acquired firms group (the censored component of the non-bankrupt firms). 
Table 4: Summary Statistics for Accounting, Market, and Economic Model Predictor Variables

Variable tLMTA NIMTA CFMTA EXRET SIGMA PRICE RSIZE LONGSHT TBR INFL

\begin{tabular}{|c|c|c|c|c|c|c|c|c|c|c|}
\hline \multicolumn{11}{|c|}{ Panel A: Full Sample } \\
\hline Mean & 0.399 & 0.021 & 0.046 & -0.022 & 0.135 & 1.555 & -2.920 & 0.123 & 8.170 & 0.446 \\
\hline Median & 0.378 & 0.034 & 0.047 & -0.011 & 0.097 & 0.980 & -3.064 & -0.040 & 7.020 & 0.444 \\
\hline St. Dev & 0.230 & 0.060 & 0.081 & 0.123 & 0.114 & 1.619 & 1.831 & 1.992 & 3.560 & 0.215 \\
\hline Min & 0.046 & -0.152 & -0.139 & -0.341 & 0.029 & 0.010 & -5.952 & -4.830 & 3.590 & -0.061 \\
\hline $\operatorname{Max}$ & 0.836 & 0.100 & 0.200 & 0.185 & 0.472 & 5.860 & 0.721 & 6.510 & 15.720 & 0.991 \\
\hline \multicolumn{11}{|c|}{ Panel B: Bankrupt Group } \\
\hline Mean & 0.654 & -0.060 & -0.014 & -0.152 & 0.261 & 0.165 & -4.905 & -0.253 & 8.374 & 0.490 \\
\hline Median & 0.784 & -0.064 & -0.023 & -0.165 & 0.232 & 0.060 & -5.168 & -0.190 & 7.020 & 0.452 \\
\hline St. Dev & 0.244 & 0.084 & 0.110 & 0.181 & 0.156 & 0.293 & 1.104 & 1.740 & 4.040 & 0.228 \\
\hline \multicolumn{11}{|c|}{ Panel C: Non-Bankrupt Group } \\
\hline Mean & 0.396 & 0.022 & 0.046 & -0.021 & 0.133 & 1.571 & -2.898 & 0.127 & 8.168 & 0.446 \\
\hline Median & 0.375 & 0.035 & 0.047 & -0.011 & 0.096 & 1.000 & -3.040 & -0.040 & 7.020 & 0.444 \\
\hline St. Dev & 0.229 & 0.059 & 0.081 & 0.122 & 0.113 & 1.621 & 1.826 & 1.995 & 3.555 & 0.215 \\
\hline \multicolumn{11}{|c|}{ Panel D: Acquired Firms Group } \\
\hline Mean & 0.418 & 0.033 & 0.063 & -0.015 & 0.120 & 1.535 & -2.645 & 0.182 & 9.188 & 0.444 \\
\hline Median & 0.400 & 0.039 & 0.065 & -0.008 & 0.092 & 1.050 & -2.786 & -0.040 & 9.380 & 0.444 \\
\hline St. Dev & 0.219 & 0.048 & 0.075 & 0.112 & 0.098 & 1.487 & 1.625 & 2.203 & 3.456 & 0.237 \\
\hline
\end{tabular}

This table shows mean, median and standard deviation for the following variables: total liabilities over market value of assets (TLMTA), net income over market value of total assets (NIMTA), cash flow over market value of total assets (CFMTA), log excess return over FTSE All Share Index (EXRET), standard deviation of firm stock returns over a six-month period (SIGMA), price per share (PRICE), log of firm's market equity over the total valuation of FTSE All Share Index (RSIZE), the term structure premium - the difference between long-term guilt rate and Treasury Bill Rate (LONGSHT), the three month Treasury Bill Rate (TBR), and the monthly RPI inflation rate (INFL). Panel A reports summary statistics for all firm observations, panels $\mathrm{B}$ and $\mathrm{C}$ report summary statistics for the bankrupt and non-bankrupt groups respectively, and panel D reports summary statistics for the acquired firms group (the censored component of the non-bankrupt firms). 
Table 5: Logit Regressions of Bankruptcy Indicator on Accounting Model Predictor Variables

\begin{tabular}{|c|c|}
\hline Variable & Coefficient \& z-value \\
\hline \multirow[t]{2}{*}{ WCTA } & -0.707 \\
\hline & $(2.94) * * *$ \\
\hline \multirow[t]{2}{*}{ TLTA } & 2.746 \\
\hline & $(10.99) * * *$ \\
\hline \multirow[t]{2}{*}{ CFTA } & -2.168 \\
\hline & $(5.44)^{* * *}$ \\
\hline \multirow[t]{2}{*}{$\mathrm{CHIN}$} & -0.743 \\
\hline & $(8.22)^{* * *}$ \\
\hline \multirow[t]{2}{*}{ INTWO } & 0.511 \\
\hline & $(4.27)^{* * *}$ \\
\hline \multirow[t]{2}{*}{ EBITSHARE } & -0.613 \\
\hline & $(5.25)^{* * *}$ \\
\hline \multirow[t]{2}{*}{ QACA } & -0.946 \\
\hline & $(5.08) * * *$ \\
\hline \multirow[t]{2}{*}{ FOPTL } & -0.703 \\
\hline & $(4.01) * * *$ \\
\hline \multirow[t]{2}{*}{ Constant } & -5.143 \\
\hline & $(22.66)^{* * *}$ \\
\hline Number of bankruptcies & 558 \\
\hline Firm-year Observations & 41545 \\
\hline Number of firms & 4454 \\
\hline Likelihood Ratio $\chi^{2}$ & $753.34 * * *$ \\
\hline Pseudo R-squared & 0.1273 \\
\hline Area under the ROC curve & 0.8124 \\
\hline
\end{tabular}

This table reports results from logit regressions of the bankruptcy indicator on the following variables: working capital over total assets (WCTA), total liabilities over total assets (TLTA), cash flow over total assets (CFTA), change in net income (CHIN), one if net income was negative for the last two years (INTWO), earnings before interest and tax over share capital (EBITSHARE), quick assets over current assets (QACA), and funds from operation over total liabilities (FOPTL). The absolute value of the $\mathrm{z}$-statistics is reported in parentheses. * denotes significance at the $10 \%$ level, $* *$ denotes significance at the $5 \%$ level and $* * *$ denotes significance at the $1 \%$ level. 
Table 6: Logit Regressions of Bankruptcy Indicator on Accounting and Market Predictor Variables

\begin{tabular}{|c|c|c|c|}
\hline \multicolumn{2}{|c|}{$\begin{array}{rr}\text { Variable } & \text { Coefficient \& } \mathrm{z}- \\
\text { value }\end{array}$} & Variable & $\begin{array}{r}\text { Coefficient \& } \mathrm{z}- \\
\text { value }\end{array}$ \\
\hline \multicolumn{2}{|c|}{$\begin{array}{c}\text { Accounting \& Market } \\
\text { Model (1) }\end{array}$} & \multicolumn{2}{|c|}{$\begin{array}{c}\text { Accounting \& Market } \\
\text { Model (2) }\end{array}$} \\
\hline \multirow[t]{2}{*}{ TLME } & 0.479 & WCMTA & -0.934 \\
\hline & $(13.83)^{* * * *}$ & & $(3.60) * * *$ \\
\hline \multirow[t]{2}{*}{ EXRET } & -2.707 & EXRET & -2.66 \\
\hline & $(8.70) * * *$ & & $(8.56) * * *$ \\
\hline \multirow[t]{2}{*}{ CFMTA } & -2.765 & CFMTA & -3.069 \\
\hline & $(4.60) * * *$ & & $(5.05)^{* * *}$ \\
\hline \multirow[t]{2}{*}{ SIGMA } & 1.757 & SIGMA & 1.984 \\
\hline & $(4.70) * * *$ & & $(5.27) * * *$ \\
\hline \multirow[t]{2}{*}{ PRICE } & -0.008 & PRICE & -0.009 \\
\hline & $(6.10) * * *$ & & $(6.08) * * *$ \\
\hline \multirow[t]{2}{*}{ NIMTA } & -3.156 & NIMTA & -3.226 \\
\hline & $(4.00)^{* * *}$ & & $(4.06) * * *$ \\
\hline \multirow[t]{2}{*}{ TLTADJ } & 0.681 & TLMTA & 2.947 \\
\hline & $(3.24) * * *$ & & $(11.38)^{* * * *}$ \\
\hline \multirow[t]{2}{*}{ RSIZE } & -0.121 & RSIZE & -0.116 \\
\hline & $(2.54)^{* *}$ & & $(2.43)^{* *}$ \\
\hline \multirow[t]{4}{*}{ Constant } & -6.102 & $\mathrm{BM}$ & 0.155 \\
\hline & $(22.11)^{* * *}$ & & $(2.61)^{* * *}$ \\
\hline & & Constant & -6.474 \\
\hline & & & $(22.19) * * *$ \\
\hline $\begin{array}{l}\text { Number of } \\
\text { bankruptcies }\end{array}$ & 428 & $\begin{array}{l}\text { Number of } \\
\text { bankruptcies }\end{array}$ & 428 \\
\hline $\begin{array}{l}\text { Firm-year } \\
\text { Observations }\end{array}$ & 39960 & $\begin{array}{l}\text { Firm-year } \\
\text { Observations }\end{array}$ & 39960 \\
\hline Number of firms & 4565 & Number of firms & 4565 \\
\hline Likelihood Ratio $\chi^{2}$ & $1199.50 * * *$ & Likelihood Ratio $\chi^{2}$ & $1180.60 * * *$ \\
\hline Pseudo R-squared & 0.2533 & Pseudo R-squared & 0.2494 \\
\hline $\begin{array}{l}\text { Area under the ROC } \\
\text { curve }\end{array}$ & 0.8992 & $\begin{array}{l}\text { Area under the ROC } \\
\text { curve }\end{array}$ & 0.8961 \\
\hline
\end{tabular}

This table reports results from logit regressions of the bankruptcy indicator on the following variables: total liabilities over market value of equity (TLME), log excess return over FTSE All Share Index (EXRET), cash flow over market value of total assets calculated by addition of firm market value and book value of total liabilities (CFMTA), standard deviation of firm stock returns over a six-month period (SIGMA), price per share (PRICE), net income over market value of total assets (NIMTA), total liabilities over adjusted total assets calculated by adding $10 \%$ of the difference between market equity and book equity (TLTADJ), and log of firm's market equity over the total valuation of FTSE All Share Index (RSIZE). The absolute 
value of the $\mathrm{z}$-statistics is reported in parentheses. * denotes significance at the $10 \%$ level, $* *$ denotes significance at the $5 \%$ level and $* * *$ denotes significance at the $1 \%$ level. 
Table 7: Logit Regressions of Bankruptcy Indicator on Accounting, Market and Economic Predictor Variables

\begin{tabular}{|c|c|c|c|c|c|}
\hline Variable & $\begin{array}{r}\text { Coefficient } \\
\text { \& Z-value }\end{array}$ & Variable & $\begin{array}{r}\text { Coefficient } \\
\text { \& Z-value }\end{array}$ & Variable & $\begin{array}{r}\text { Coefficient } \\
\text { \& } \mathrm{z} \text {-value }\end{array}$ \\
\hline \multicolumn{2}{|c|}{$\begin{array}{c}\text { Accounting \& Market } \\
\text { Model }\end{array}$} & \multicolumn{2}{|c|}{$\begin{array}{c}\text { Accounting \& Market \& } \\
\text { Economic Model (1) }\end{array}$} & \multicolumn{2}{|c|}{$\begin{array}{c}\text { Accounting \& Market \& } \\
\text { Economic Model (2) }\end{array}$} \\
\hline \multirow[t]{2}{*}{ TLME } & 0.479 & TLMTA & 3.149 & TLMTA & 3.325 \\
\hline & $(13.83)^{* * *}$ & & $(13.22) * * *$ & & $(14.34) * * *$ \\
\hline \multirow[t]{2}{*}{ EXRET } & -2.707 & EXRET & -2.705 & EXRET & -2.560 \\
\hline & $(8.70)^{* * *}$ & & $(8.61)^{* * * *}$ & & $(8.21)^{* * *}$ \\
\hline \multirow[t]{2}{*}{ CFMTA } & -2.765 & $\overline{\text { CFMTA }}$ & -2.444 & $\overline{\text { CFMTA }}$ & -2.449 \\
\hline & $(4.60)^{* * *}$ & & $(4.10)^{* * *}$ & & $(4.10)^{* * *}$ \\
\hline \multirow[t]{2}{*}{ SIGMA } & 1.757 & SIGMA & 2.132 & SIGMA & 2.084 \\
\hline & $(4.70)^{* * *}$ & & $(5.55)^{* * *}$ & & $(5.46) * * *$ \\
\hline \multirow[t]{2}{*}{ PRICE } & -0.008 & PRICE & -0.008 & PRICE & -0.009 \\
\hline & $(6.10)^{* * *}$ & & $(5.71)^{* * *}$ & & $(6.06)^{* * *}$ \\
\hline \multirow[t]{2}{*}{ NIMTA } & -3.156 & NIMTA & -5.024 & NIMTA & -4.832 \\
\hline & $(4.00)^{* * *}$ & & $(6.35)^{* * *}$ & & $(6.10)^{* * *}$ \\
\hline \multirow[t]{2}{*}{ TLTADJ } & 0.681 & RSIZE & -0.185 & RSIZE & -0.143 \\
\hline & $(3.24)^{* * *}$ & & $(3.52)^{* * *}$ & & $(2.85)^{* * *}$ \\
\hline \multirow[t]{2}{*}{ RSIZE } & -0.121 & LONGSHT & -0.117 & LONGSHT & -0.207 \\
\hline & $(2.54)^{* *}$ & & $(2.55)^{* * *}$ & & $(6.03)^{* * *}$ \\
\hline \multirow[t]{6}{*}{ Constant } & -6.102 & TBR & 0.068 & DEFLTBR & 0.0310 \\
\hline & $(22.11)^{* * *}$ & & $(3.39)^{* * *}$ & & $(1.90)^{*}$ \\
\hline & & INFL & 0.588 & INDPROD & -0.252 \\
\hline & & & $(2.12)^{* *}$ & & $(2.83)^{* * *}$ \\
\hline & & Constant & -7.759 & Constant & -6.839 \\
\hline & & & $(19.84)^{* * *}$ & & $(22.37)^{* * *}$ \\
\hline $\begin{array}{l}\text { Number of } \\
\text { bankruptcies }\end{array}$ & 428 & $\begin{array}{l}\text { Number of } \\
\text { bankruptcies }\end{array}$ & 428 & $\begin{array}{l}\text { Number of } \\
\text { bankruptcies }\end{array}$ & 428 \\
\hline $\begin{array}{l}\text { Firm-year } \\
\text { Observations }\end{array}$ & 39960 & $\begin{array}{l}\text { Firm-year } \\
\text { Observations }\end{array}$ & 39960 & $\begin{array}{l}\text { Firm-year } \\
\text { Observations }\end{array}$ & 39960 \\
\hline $\begin{array}{l}\text { Number of } \\
\text { firms }\end{array}$ & 4565 & $\begin{array}{l}\text { Number of } \\
\text { firms }\end{array}$ & 4565 & $\begin{array}{l}\text { Number of } \\
\text { firms }\end{array}$ & 4565 \\
\hline $\begin{array}{l}\text { Likelihood } \\
\text { Ratio } \chi^{2}\end{array}$ & $1199.50 * * *$ & $\begin{array}{l}\text { Likelihood } \\
\text { Ratio } \chi^{2} \\
\end{array}$ & $1241.23^{* * *}$ & $\begin{array}{l}\text { Likelihood } \\
\text { Ratio } \chi^{2}\end{array}$ & $1234.17 * * *$ \\
\hline $\begin{array}{l}\text { Pseudo R- } \\
\text { squared }\end{array}$ & 0.2533 & $\begin{array}{l}\text { Pseudo R- } \\
\text { squared }\end{array}$ & 0.2622 & $\begin{array}{l}\text { Pseudo R- } \\
\text { squared }\end{array}$ & 0.2607 \\
\hline $\begin{array}{l}\text { Area under the } \\
\text { ROC curve }\end{array}$ & 0.8992 & $\begin{array}{l}\text { Area under the } \\
\text { ROC curve }\end{array}$ & 0.9034 & $\begin{array}{l}\text { Area under the } \\
\text { ROC curve }\end{array}$ & 0.9029 \\
\hline
\end{tabular}

This table reports results from logit regressions of the bankruptcy indicator on the following variables: total liabilities over market value of equity (TLME), log excess return over FTSE All Share Index (EXRET), cash flow over market value of total assets calculated by addition of firm market value and book value of total liabilities (CFMTA), standard deviation of firm stock returns over a six-month period (SIGMA), price per share (PRICE), net income over market value of total assets (NIMTA), total liabilities over adjusted total assets calculated by adding $10 \%$ of the difference between market equity and book equity (TLTADJ), log of firm's market 
equity over the total valuation of FTSE All Share Index (RSIZE), ), the term structure premium - the difference between long-term guilt rate and Treasury Bill Rate (LONGSHT), the three month Treasury Bill Rate (TBR), and the monthly RPI inflation rate (INFL). The absolute value of the $\mathrm{z}$-statistics is reported in parentheses. $*$ denotes significance at the $10 \%$ level, $* *$ denotes significance at the $5 \%$ level and $* * *$ denotes significance at the $1 \%$ level. 
Table 8: Logit Regressions of Bankruptcy Indicator on Predictor Variables with influential observations deleted

\begin{tabular}{|c|c|c|c|c|c|}
\hline \multicolumn{2}{|c|}{$\begin{array}{rr}\text { Variable } & \begin{array}{r}\text { Coefficient } \\
\text { \& z-value }\end{array}\end{array}$} & \multicolumn{2}{|c|}{$\begin{array}{rr}\text { Variable } & \begin{array}{r}\text { Coefficient } \\
\text { \& z-value }\end{array}\end{array}$} & Variable & $\begin{array}{r}\text { Coefficient } \\
\text { \& z-value }\end{array}$ \\
\hline \multicolumn{2}{|c|}{$\begin{array}{c}\text { Accounting \& Market } \\
\text { Model }\end{array}$} & \multicolumn{2}{|c|}{$\begin{array}{c}\text { Accounting \& Market \& } \\
\text { Economic Model (1) }\end{array}$} & \multicolumn{2}{|c|}{$\begin{array}{l}\text { Accounting \& Market \& } \\
\text { Economic Model (2) }\end{array}$} \\
\hline \multirow[t]{2}{*}{ TLME } & 0.503 & TLMTA & 3.468 & TLMTA & 3.664 \\
\hline & $(13.97)^{* * *}$ & & $(13.46)^{* * *}$ & & $(14.60)^{* * *}$ \\
\hline \multirow[t]{2}{*}{ EXRET } & -2.661 & EXRET & -2.656 & EXRET & -2.509 \\
\hline & $(8.35)^{* * *}$ & & $(8.25)^{* * *}$ & & $(7.86)^{* * *}$ \\
\hline \multirow[t]{2}{*}{ CFMTA } & -2.656 & CFMTA & -2.406 & CFMTA & -2.395 \\
\hline & $(4.32)^{* * *}$ & & $(3.95)^{* * *}$ & & $(3.92)^{* * *}$ \\
\hline \multirow[t]{2}{*}{ SIGMA } & 1.637 & SIGMA & 2.032 & SIGMA & 1.979 \\
\hline & $(4.22)^{* * *}$ & & $(5.08) * * *$ & & $(4.99)^{* * *}$ \\
\hline \multirow[t]{2}{*}{ PRICE } & -0.019 & PRICE & -0.019 & PRICE & -0.020 \\
\hline & $(7.96)^{* * *}$ & & $(7.82)^{* * *}$ & & $(8.08)^{* * *}$ \\
\hline \multirow[t]{2}{*}{ NIMTA } & -2.571 & NIMTA & -4.496 & NIMTA & -4.308 \\
\hline & $(3.17)^{* * *}$ & & $(5.52) * * *$ & & $(5.29)^{* * *}$ \\
\hline \multirow[t]{2}{*}{ TLTADJ } & 0.668 & RSIZE & -0.181 & RSIZE & -0.130 \\
\hline & $(3.06) * * *$ & & $(3.09)^{* * *}$ & & $(2.34)^{* *}$ \\
\hline \multirow[t]{2}{*}{ RSIZE } & -0.097 & LONGSHT & -0.130 & LONGSHT & -0.231 \\
\hline & $(1.88)^{*}$ & & $(2.68) * * *$ & & $(6.36)^{* * *}$ \\
\hline \multirow[t]{6}{*}{ Constant } & -5.798 & TBR & 0.081 & DEFLTBR & 0.040 \\
\hline & $(18.95)^{* * *}$ & & $(3.85)^{* * *}$ & & $(2.33)^{* *}$ \\
\hline & & INFL & 0.532 & INDPROD & -0.255 \\
\hline & & & $(1.84)^{*}$ & & $(2.71)^{* * *}$ \\
\hline & & Constant & -7.765 & Constant & -6.757 \\
\hline & & & $(17.89)^{* *}$ & & $(19.66)^{* * *}$ \\
\hline $\begin{array}{l}\text { Number of } \\
\text { bankruptcies }\end{array}$ & 398 & $\begin{array}{l}\text { Number of } \\
\text { bankruptcies }\end{array}$ & 398 & $\begin{array}{l}\text { Number of } \\
\text { bankruptcies }\end{array}$ & 398 \\
\hline $\begin{array}{l}\text { Firm-year } \\
\text { Observations }\end{array}$ & 39925 & $\begin{array}{l}\text { Firm-year } \\
\text { Observations }\end{array}$ & 39925 & $\begin{array}{l}\text { Firm-year } \\
\text { Observations }\end{array}$ & 39925 \\
\hline $\begin{array}{l}\text { Number of } \\
\text { firms }\end{array}$ & 4562 & $\begin{array}{l}\text { Number of } \\
\text { firms }\end{array}$ & 4562 & $\begin{array}{l}\text { Number of } \\
\text { firms }\end{array}$ & 4562 \\
\hline $\begin{array}{l}\text { Likelihood } \\
\text { Ratio } \chi^{2}\end{array}$ & $1335.11 * * *$ & $\begin{array}{l}\text { Likelihood } \\
\text { Ratio } \chi^{2}\end{array}$ & $1399.07 * * *$ & $\begin{array}{l}\text { Likelihood } \\
\text { Ratio } \chi^{2}\end{array}$ & $1390.18 * * *$ \\
\hline $\begin{array}{l}\text { Pseudo R- } \\
\text { squared }\end{array}$ & 0.2993 & $\begin{array}{l}\text { Pseudo R- } \\
\text { squared }\end{array}$ & 0.3137 & $\begin{array}{l}\text { Pseudo R- } \\
\text { squared }\end{array}$ & 0.3117 \\
\hline $\begin{array}{l}\text { Area under the } \\
\text { ROC curve }\end{array}$ & 0.9283 & $\begin{array}{l}\text { Area under the } \\
\text { ROC curve }\end{array}$ & 0.9340 & $\begin{array}{l}\text { Area under the } \\
\text { ROC curve }\end{array}$ & 0.9332 \\
\hline
\end{tabular}

This table reports results from logit regressions of the bankruptcy indicator on the following variables with influential observations deleted: total liabilities over market value of equity (TLME), log excess return over FTSE All Share Index (EXRET), cash flow over market value of total assets calculated by addition of firm market value and book value of total liabilities (CFMTA), standard deviation of firm stock returns over a six-month period (SIGMA), price per share (PRICE), net income over market value of total assets (NIMTA), total liabilities over adjusted total assets calculated by adding $10 \%$ of the difference between market equity and book equity (TLTADJ), log 
of firm's market equity over the total valuation of FTSE All Share Index (RSIZE), the term structure premium - the difference between long-term guilt rate and Treasury Bill Rate (LONGSHT), the three month Treasury Bill Rate (TBR), and the monthly RPI inflation rate (INFL). The absolute value of the $\mathrm{z}$-statistics is reported in parentheses. $*$ denotes significance at the $10 \%$ level, $* *$ denotes significance at the $5 \%$ level and $* * *$ denotes significance at the $1 \%$ level. 
Table 9: Hosmer-Lemeshow Statistic for the Accounting, Market and Economic

Model

\begin{tabular}{|c|c|c|c|c|c|c|}
\hline Group & $\mathbf{N}$ & Obs & $(\%)$ & Exp & $(\%)$ & HL \\
\hline 1 & 3993 & 0 & 0 & 0 & 0 & 0 \\
\hline 2 & 3993 & 0 & 0 & 0 & 0 & 0 \\
\hline 3 & 3992 & 0 & 0 & 0.2 & 0 & 0.2 \\
\hline 4 & 3993 & 0 & 0 & 0.7 & 0 & 0.7 \\
\hline 5 & 3992 & 0 & 0 & 2 & 0 & 2 \\
\hline 6 & 3993 & 1 & 0 & 4.8 & 0.1 & 3 \\
\hline 7 & 3993 & 13 & 0.3 & 10.5 & 0.3 & 0.6 \\
\hline 8 & 3992 & 24 & 0.6 & 22.9 & 0.6 & 0.1 \\
\hline 9 & 3993 & 60 & 1.5 & 55.5 & 1.4 & 0.4 \\
\hline 10 & 3992 & 300 & 7.5 & 301.5 & 7.6 & 0 \\
\hline Total & 39926 & 398 & 1 & 398 & 1 & 6.8 \\
\hline \multicolumn{3}{|c|}{ Number of observations } & & 39925 & & \\
\hline \multicolumn{3}{|c|}{ Hosmer-Lemeshow $\chi^{2}$} & & 6.80 & & \\
\hline $\begin{array}{l}\text { Prob > } \\
\text { chi2 }\end{array}$ & & & & 0.5579 & & \\
\hline
\end{tabular}

The table reports the goodness-of-fit of the Accounting, Market and Economic Model (1) from Table 8 as measured by the Hosmer-Lemeshow (2000) statistic. 
Table 10: In-Sample and Out-of-Sample Forecast Accuracy of Accounting, Market and Economic Model (1)

\begin{tabular}{|c|c|c|}
\hline Group & In-sample & Out-of-Sample \\
\hline 1 & $0.00 \%$ & $0.00 \%$ \\
\hline 2 & $0.00 \%$ & $0.00 \%$ \\
\hline 3 & $0.02 \%$ & $0.00 \%$ \\
\hline 4 & $0.18 \%$ & $0.12 \%$ \\
\hline 5 & $0.50 \%$ & $0.33 \%$ \\
\hline 6 & $1.21 \%$ & $0.91 \%$ \\
\hline 7 & $2.64 \%$ & $2.18 \%$ \\
\hline 8 & $5.75 \%$ & $4.94 \%$ \\
\hline 9 & $13.94 \%$ & $12.89 \%$ \\
\hline 10 & $75.75 \%$ & $78.63 \%$ \\
\hline 6 to 10 & $99.30 \%$ & $99.55 \%$ \\
\hline
\end{tabular}

For the in-sample test, the Accounting, Market and Economic Model (1) from Table 8 is used to estimate the forecast bankruptcy probabilities with data from 1978-2006. The probabilities are calculated for each year and the companies are then grouped into deciles based on the default probabilities. The number of bankruptcies in each decile for each year are aggregated over 1978-2006 and reported in the table. For the out-ofsample test, the model is initially estimated with data from 1978-1991 and used to forecast bankruptcy probabilities for 1992-2006. This process is then rolled on annually. The probabilities are calculated for each year and the companies are grouped into deciles based on the default probabilities. The number of bankruptcies in each decile for each year are aggregated over 1992-2006 and reported in the table. Group 1 represent firms with low predicted bankrupt probabilities; Group 10 represents firms with high predicted bankrupt probabilities. 
Table 11: Type I and Type II Errors of Accounting, Market, and Economic model

\begin{tabular}{|c|c|c|c|c|c|c|}
\hline \multirow{2}{*}{$\begin{array}{l}\text { Probability } \\
\text { Cutpoint }\end{array}$} & \multicolumn{2}{|c|}{ True signal } & \multicolumn{2}{|c|}{ False Signal } & \multirow{2}{*}{$\begin{array}{l}\text { Average } \\
\text { error }\end{array}$} & \multirow{2}{*}{$\begin{array}{l}\text { Overall } \\
\text { accuracy }\end{array}$} \\
\hline & Sensitivity & Specificity & Type I & Type II & & \\
\hline 0.005 & $94.47 \%$ & $74.26 \%$ & $5.53 \%$ & $25.74 \%$ & $15.64 \%$ & $74.46 \%$ \\
\hline 0.006 & $93.72 \%$ & $76.67 \%$ & $6.28 \%$ & $23.33 \%$ & $14.81 \%$ & $76.84 \%$ \\
\hline 0.007 & $92.96 \%$ & $78.59 \%$ & $7.04 \%$ & $21.41 \%$ & $14.23 \%$ & $78.74 \%$ \\
\hline 0.008 & $90.70 \%$ & $80.22 \%$ & $9.30 \%$ & $19.78 \%$ & $14.54 \%$ & $80.32 \%$ \\
\hline 0.009 & $89.70 \%$ & $81.62 \%$ & $10.30 \%$ & $18.38 \%$ & $14.34 \%$ & $81.70 \%$ \\
\hline 0.0091 & $89.70 \%$ & $81.75 \%$ & $10.30 \%$ & $18.25 \%$ & $14.28 \%$ & $81.83 \%$ \\
\hline 0.0092 & $89.70 \%$ & $81.89 \%$ & $10.30 \%$ & $18.11 \%$ & $14.21 \%$ & $81.97 \%$ \\
\hline 0.0093 & $89.45 \%$ & $82.02 \%$ & $10.55 \%$ & $17.98 \%$ & $14.27 \%$ & $82.09 \%$ \\
\hline 0.0094 & $88.94 \%$ & $82.15 \%$ & $11.06 \%$ & $17.85 \%$ & $14.46 \%$ & $82.22 \%$ \\
\hline 0.0095 & $88.44 \%$ & $82.32 \%$ & $11.56 \%$ & $17.68 \%$ & $14.62 \%$ & $82.38 \%$ \\
\hline 0.01 & $88.19 \%$ & $82.93 \%$ & $11.81 \%$ & $17.07 \%$ & $14.44 \%$ & $82.98 \%$ \\
\hline 0.015 & $82.91 \%$ & $87.07 \%$ & $17.09 \%$ & $12.93 \%$ & $15.01 \%$ & $87.03 \%$ \\
\hline 0.02 & $77.14 \%$ & $89.50 \%$ & $22.86 \%$ & $10.50 \%$ & $16.68 \%$ & $89.38 \%$ \\
\hline 0.025 & $73.87 \%$ & $91.36 \%$ & $26.13 \%$ & $8.64 \%$ & $17.39 \%$ & $91.19 \%$ \\
\hline 0.03 & $70.35 \%$ & $92.60 \%$ & $29.65 \%$ & $7.40 \%$ & $18.53 \%$ & $92.37 \%$ \\
\hline 0.04 & $65.58 \%$ & $94.47 \%$ & $34.42 \%$ & $5.53 \%$ & $19.98 \%$ & $94.19 \%$ \\
\hline 0.05 & $61.06 \%$ & $95.54 \%$ & $38.94 \%$ & $4.46 \%$ & $21.70 \%$ & $95.19 \%$ \\
\hline 0.10 & $38.44 \%$ & $98.29 \%$ & $61.56 \%$ & $1.71 \%$ & $31.64 \%$ & $97.69 \%$ \\
\hline 0.20 & $16.08 \%$ & $99.50 \%$ & $83.92 \%$ & $0.50 \%$ & $42.21 \%$ & $98.67 \%$ \\
\hline 0.30 & $6.28 \%$ & $99.84 \%$ & $93.72 \%$ & $0.16 \%$ & $46.94 \%$ & $98.91 \%$ \\
\hline 0.40 & $2.01 \%$ & $99.97 \%$ & $97.99 \%$ & $0.03 \%$ & $49.01 \%$ & $98.99 \%$ \\
\hline 0.50 & $0.25 \%$ & $100.00 \%$ & $99.75 \%$ & $0.00 \%$ & $49.88 \%$ & $99.01 \%$ \\
\hline 0.60 & $0.00 \%$ & $100.00 \%$ & $100.00 \%$ & $0.00 \%$ & $50.00 \%$ & $99.00 \%$ \\
\hline
\end{tabular}


Table 12: Accounting, Market and Economic Model, with Industry Effects

\begin{tabular}{|c|c|c|}
\hline Variable & Coefficient & t-statistic \\
\hline Constant & -8.00 & $(15.90)^{* * *}$ \\
\hline TLMTA & 4.163 & $(9.65)^{* * *}$ \\
\hline EXRET & -2.699 & $(8.34) * * *$ \\
\hline CFMTA & -2.711 & $(4.36) * * *$ \\
\hline SIGMA & 2.032 & $(5.06) * * *$ \\
\hline PRICE & -0.019 & $(7.75)^{* * *}$ \\
\hline NIMTA & -5.654 & $(5.56) * * *$ \\
\hline RSIZE & -0.167 & $(2.84)^{* * *}$ \\
\hline LONGSHT & -0.145 & $(3.00) * * *$ \\
\hline TBR & 0.065 & $(3.04) * * *$ \\
\hline INFL & 0.637 & $(2.18)^{* *}$ \\
\hline IND2 & 0.892 & $(2.17)^{* *}$ \\
\hline IND3 & 0.239 & $(0.41)$ \\
\hline IND4 & 0.636 & $(1.02)$ \\
\hline IND5 & 0.048 & $(0.07)$ \\
\hline TLMTA*IND2 & -1.333 & $(2.21)^{* *}$ \\
\hline TLMTA*IND3 & -0.837 & $(1.04)$ \\
\hline TLMTA*IND4 & -2.628 & $(2.73) * * *$ \\
\hline TLMTA*IND5 & -1.731 & $(1.49)$ \\
\hline NIMTA*IND2 & 3.925 & $(2.53)^{* *}$ \\
\hline NIMTA*IND3 & 1.442 & $(0.65)$ \\
\hline NIMTA*IND4 & -0.987 & $(0.31)$ \\
\hline NIMTA*IND5 & -1.927 & $(0.44)$ \\
\hline Number of bankruptcies & 398 & \\
\hline Firm-year Observations & 39925 & \\
\hline Number of firms & 4562 & \\
\hline Likelihood Ratio $\chi^{2}$ & $1432.6^{* *}$ & \\
\hline Pseudo R-squared & 0.3212 & \\
\hline Area under the ROC curve & 0.9358 & \\
\hline
\end{tabular}

This table reports results from logit regressions of the bankruptcy indicators on the following variables with influential observations deleted: total liabilities over market value of equity (TLME), log excess return over FTSE All Share Index (EXRET), cash flow over market value of total assets calculated by addition of firm market value and book value of total liabilities (CFMTA), standard deviation of firm stock returns over a six-month period (SIGMA), price per share (PRICE), net income over market value of total assets (NIMTA), total liabilities over adjusted total assets calculated by adding $10 \%$ of the difference between market equity and book equity (TLTADJ), log of firm's market equity over the total valuation of FTSE All Share Index (RSIZE), the term structure premium - the difference between long-term guilt rate and Treasury Bill Rate (LONGSHT), the three month Treasury Bill Rate (TBR), and the monthly RPI inflation rate (INFL). The five industry groups, represented by dummy variables are: IND1 - Manufacturing: Industrials and Consumer Goods (the base case); IND2 - 
Services: Consumer Services, Healthcare, Telecommunication, Utilities; IND3 Financials; IND4 - Technology; and IND5 - Oil \& Gas and Basic Materials.

The absolute value of the $\mathrm{z}$-statistics is reported in parentheses. * denotes significance at the $10 \%$ level, $* *$ denotes significance at the $5 \%$ level and $* * *$ denotes significance at the $1 \%$ level. 
Table 13: Forecast Accuracy of in-sample and out-of-sample performance with Industry Effects

For the in-sample test, the model estimated the forecast bankruptcy probabilities with data from 1978-2006. The probabilities are calculated for each year and the companies are then grouped into deciles based on the default probabilities. The number of bankruptcies in each decile for each year are aggregated over 1978-2006 and reported in the table. For the out-of-sample test, the model estimated with data from 1978-1991 with yearly observation intervals is used to forecast bankruptcy probabilities for 1992-2006. This process is then rolled on annually. The probabilities are calculated for each year and the companies are then grouped into deciles based on the default probabilities. The number of bankruptcies in each decile for each year are aggregated over 1992-2006 and reported in the table. Group 1 represent firms with low predicted bankrupt probabilities; Group 10 represents firms with high predicted bankrupt probabilities.

\begin{tabular}{|c|r|r|r|r|}
\hline \multirow{2}{*}{ Group } & \multicolumn{3}{c|}{ Out-of-Sample } \\
& $\begin{array}{c}\text { No } \\
\text { Industry } \\
\text { Effects }\end{array}$ & $\begin{array}{c}\text { With } \\
\text { Industry } \\
\text { Effects }\end{array}$ & $\begin{array}{c}\text { No } \\
\text { Industry } \\
\text { Effects }\end{array}$ & $\begin{array}{c}\text { With } \\
\text { Industry } \\
\text { Effects }\end{array}$ \\
\hline 1 & 0.00 & 0.00 & 0.00 & 0.00 \\
\hline 2 & 0.00 & 0.00 & 0.00 & 0.00 \\
\hline 3 & 0.02 & 0.05 & 0.00 & 0.00 \\
\hline 4 & 0.18 & 0.15 & 0.12 & 0.07 \\
\hline 5 & 0.50 & 0.45 & 0.33 & 0.25 \\
\hline 6 & 1.21 & 1.11 & 0.91 & 0.72 \\
\hline 7 & 2.64 & 2.49 & 2.18 & 1.87 \\
\hline 8 & 5.75 & 5.50 & 4.94 & 4.60 \\
\hline 9 & 13.94 & 13.69 & 12.89 & 12.72 \\
\hline 10 & 75.75 & 76.56 & 78.63 & 79.76 \\
\hline 6 to 10 & 99.30 & 99.35 & 99.55 & 99.68 \\
\hline
\end{tabular}


Appendix: Pure Accounting Model With Industry Effects

\begin{tabular}{|c|c|c|}
\hline Variable & Coefficient & t-statistic \\
\hline Constant & -5.603 & $(18.43)^{* * *}$ \\
\hline TLTA & 3.730 & $(9.64)^{* * *}$ \\
\hline WCTA & -1.065 & $(4.09) * * *$ \\
\hline CFTA & -2.131 & $(4.30) * * *$ \\
\hline CHIN & -0.758 & $(8.12)^{* * *}$ \\
\hline INTWO & 0.543 & $(4.40) * * *$ \\
\hline EBITSHARE & -0.639 & $(5.30) * * *$ \\
\hline QACA & -0.916 & $(4.64) * * *$ \\
\hline FOPTL & -0.728 & $(3.88) * * *$ \\
\hline & & \\
\hline IND2 & 0.638 & $(1.82)^{*}$ \\
\hline IND3 & 0.225 & $(0.46)$ \\
\hline IND4 & 0.307 & $(0.51)$ \\
\hline IND5 & 0.684 & $(1.33)$ \\
\hline TLTA*IND2 & -1.774 & $(3.35)^{* * *}$ \\
\hline TLTA*IND3 & -0.663 & $(0.92)$ \\
\hline TLTA*IND4 & -3.290 & $(4.24) * * *$ \\
\hline TLTA*IND5 & -2.649 & $(2.76) * * *$ \\
\hline CFTA*IND2 & -0.206 & $(0.29)$ \\
\hline CFTA*IND3 & 0.521 & $(0.50)$ \\
\hline CFTA*IND4 & -4.670 & $(2.67) * * *$ \\
\hline CFTA*IND5 & 0.206 & $(0.13)$ \\
\hline Number of bankruptcies & 531 & \\
\hline Firm-year Observations & 41513 & \\
\hline Number of firms & 4454 & \\
\hline Likelihood Ratio $\chi^{2}$ & $855.62 * *$ & \\
\hline Pseudo R-squared & 0.1505 & \\
\hline Area under the ROC curve & 0.8331 & \\
\hline
\end{tabular}

This table reports results from logit regressions of the bankruptcy indicators on the following variables: working capital over total assets (WCTA), total liabilities over total assets (TLTA), cash flow over total assets (CFTA), change in net income (CHIN), one if net income was negative for the last two years (INTWO), earnings before interest and tax over share capital (EBITSHARE), quick assets over current assets (QACA), and funds from operation over total liabilities (FOPTL). The five industry groups, represented by dummy variables are: IND1 - Manufacturing: Industrials and Consumer Goods (the base case); IND2 - Services: Consumer Services, Healthcare, Telecommunication, Utilities; IND3 - Financials; IND4 Technology; and IND5 - Oil \& Gas and Basic Materials. The absolute value of the zstatistics is reported in parentheses. * denotes significance at the $10 \%$ level, **denotes significance at the $5 \%$ level and $* * *$ denotes significance at the $1 \%$ level. 